\title{
Impact of Carbonate Precipitation on Riverine Inorganic Carbon Mass Transport from a Mid-continent, Forested Watershed
}

\author{
KATHRYN SZRAMEK ${ }^{\star}$ and LYNN M. WALTER \\ Department of Geological Sciences, University of Michigan, 2534 C.C. Little Bldg., Ann Arbor, MI \\ 48109, U.S.A.
}

\begin{abstract}
Physiochemical controls on the carbonate geochemistry of large river systems are important regulators of carbon exchange between terrestrial and marine reservoirs on human time scales. Although many studies have focused on large-scale river carbon fluxes, there are few investigations of mechanistic aspects of carbonate mass balance and transport at the catchment scale. We determined elemental and carbonate geochemistry and mass balances for net carbonate dissolution fluxes from the forested, mid-latitude Huron River watershed, established on carbonate-rich unconfined glacial drift aquifers. Shallow groundwaters are near equilibrium with respect to calcite at $p \mathrm{CO}_{2}$ values up to 25 times atmospheric values. Surface waters are largely groundwater fed and exhibit chemical evolution due to $\mathrm{CO}_{2}$ degassing, carbonate precipitation in lakes and wetlands, and anthropogenic introduction of road salts $\left(\mathrm{NaCl}\right.$ and $\left.\mathrm{CaCl}_{2}\right)$. Because the source groundwater $\mathrm{Mg}^{2+} / \mathrm{HCO}_{3}^{-}$ratio is fairly constant, this parameter permits mass balances to be made between carbonate dissolution and back precipitation after groundwater discharge. Typically, precipitation does not occur until IAP/K calcite values exceed 10 times supersaturation. Stream chemistry changes little thereafter even though streams remain highly supersaturated for calcite. Our data taken together with historical United States Geological Survey (USGS) data show that alkalinity losses to carbonate precipitation are most significant during periods of lowest discharge. Thus, on an annual basis, the large carbon flux from carbonate dissolution in soil zones is only decreased by a relatively small amount by the back precipitation of calcium carbonate.
\end{abstract}

Key words: calcite saturation, carbon, Michigan, rivers, alkalinity

\section{Introduction}

The dissolution and precipitation of carbonate minerals in aqueous surficial environments play an important role in the transformation of terrestrial organic to inorganic carbon reservoirs. Given the great reactivity and solubility of carbonates, the flux from carbonate dissolution to ground and surface waters is limited largely by the volume of water and soil zone $p \mathrm{CO}_{2}$ in

^ Author for correspondence: E-mail: kszramek@umich.edu 
open systems (e.g., Reardon et al., 1979; Van Breenan and Protz, 1988). Enhanced mineral weathering is one likely response to predicted global warming, enhanced biosphere carbon cycling, and changes in land use, (e.g., Mackenzie et al., 1993; Mackenzie et al., 1998). Enhanced carbonate and silicate mineral dissolution has recently been documented in experimental tree growth mesocosms maintained at elevated $\mathrm{CO}_{2}$ and nitrogen fertility levels (Andrews and Schlesinger, 2001; Hamilton et al., 2002; Williams et al., 2003). Here, soil zone $p \mathrm{CO}_{2}$ profiles are controlled by root and microbial respiration rates which increase with enhanced growth under elevated $\mathrm{CO}_{2}$ (the "fertilization effect") and with N-fertility (Pregitzer et al., 2000).

An increase in the mass of terrestrial carbon reservoirs through $\mathrm{CO}_{2}$ fertilization, enhanced biosphere carbon transformation rates, and changes in land use in turn may increase the amount of inorganic carbon carried in rivers and discharged into the world's oceans. Early investigations of riverine fluxes focused on inorganic carbon contents and speciation in major world rivers (e.g., Kempe, 1982 and references therein) and solute sources and mass balances from major world river basins (e.g., Meybeck, 1987 and references therein). Recent studies on large-scale riverine solute fluxes have focused on two main aspects of the weathering process, $\mathrm{CO}_{2}$ consumption from silicate weathering (e.g., Aucour et al., 1999; Gaillardet et al., 1999; Mortatti and Probst, 2003) and the separation of organic vs. inorganic carbon sources using carbon and strontium isotopic tracers (e.g., Barth et al., 2003; Karim and Veizer, 2000; Telmer and Veizer, 1999).

In classic treatments of riverine carbonate chemistry (Berner and Berner, 1987; Garrells and Mackenzie, 1971; Holland, 1978), the relation between dissolved $\mathrm{Ca}^{+2}$ and $\mathrm{HCO}_{3}^{-}$concentrations is considered relative to theoretical $\mathrm{CO}_{2}$ partial pressures and equilibrium with respect to calcite. In this case the $\mathrm{Ca}^{2+}-\mathrm{HCO}_{3}^{-}$relations in most world rivers were considered to reflect near-equilibrium conditions with respect to calcite, requiring supersaturation with respect to atmospheric $\mathrm{CO}_{2}$. This assumption was supported by the fact that calcite saturation indices for major world river systems are nearly all at or below equilibrium with respect to calcite (Kempe, 1982). In landscapes where carbonate groundwaters discharge into river systems, degassing of $\mathrm{CO}_{2}$ typically leads to calcite saturation and calcium carbonate precipitation (e.g., Herman and Lorah, 1987; Jacobson and Usdowski, 1975; Lu et al., 2000).

Investigations of streams draining carbonate-bearing watersheds have observed a decrease in alkalinity concentrations at low and high discharge conditions (Grosbois et al., 2000; Roy et al., 1999), but few have characterized the carbonate saturation dynamics of riverine systems on smaller catchment scale.

Recently, Telmer and Veizer (1999) suggest that different catchments in the St. Lawrence River drainage have variable soil zone $p \mathrm{CO}_{2}$ values due 
to different thickness of soils in each basin. This could produce a higher $p \mathrm{CO}_{2}$ value of the weathering zone in some basins, in turn generating higher dissolved inorganic carbonate loads from such regions. Importantly, a recent study of the Mississippi River drainage system has revealed a significant increase in alkalinity concentrations and fluxes over the past 50 years (Raymond and Cole, 2003). With the use of data from smaller catchments in the Mississippi drainage, patterns of land use are considered to drive this increase with agricultural catchments having the highest alkalinity concentrations. However, the possibility of retention of carbonate alkalinity within a catchment was not considered and may also play a role. Because many glaciated mid-continent watersheds contain calcareous wetlands (fens) and marl lakes (e.g., Almendinger and Leete, 1998a,b; Dustin et al., 1986; Glaser et al., 1990, Komor, 1994), it is reasonable to expect some decrease in net export of $\mathrm{HCO}_{3}^{-}$by carbonate precipitation in these environments. Thus, without a reasonable geochemical mass balance of dissolved solutes in source waters and sinks, it is difficult to attribute changes in riverine alkalinity values unequivocally to changes in carbon cycling of landscapes and land use types.

In this paper, we present results of a study of ground and surface water elemental and carbonate system geochemistry in catchments of the Huron River watershed located in the relatively recently deglaciated mid-continent region of the United States. The relation of topographic gradients and internal permeability differentials in glacial drift aquifer systems produce a very close coupling between unconfined groundwaters and surface water drainages (Grannemann et al., 2000). This permits us to establish fundamental geochemical characteristics of groundwaters and to follow the chemical evolution of surface waters in catchments as they pass through carbonate fens and marl lakes into the main channel of the Huron River. Using these geochemical data, we arrive at mass balances of dissolution and precipitation and investigate how these are related to degree of carbonate mineral saturation and $p \mathrm{CO}_{2}$. Finally, we integrate these mass balances with historical discharge and chemical data available from United States Geological Survey (USGS) Huron River gauging stations to evaluate how significantly carbonate precipitation reduces net riverine inorganic carbon fluxes.

\section{Materials and Methods}

\subsection{THE HURON WATERSHED AND SITE CHARACTERIZATION}

The Huron River watershed is located in the southeastern corner of the Lower Peninsula of Michigan (Figure 1a and b) and has a mean annual temperature of $10{ }^{\circ} \mathrm{C}$ and average annual precipitation of $84 \mathrm{~cm}$. The Huron 
(a)

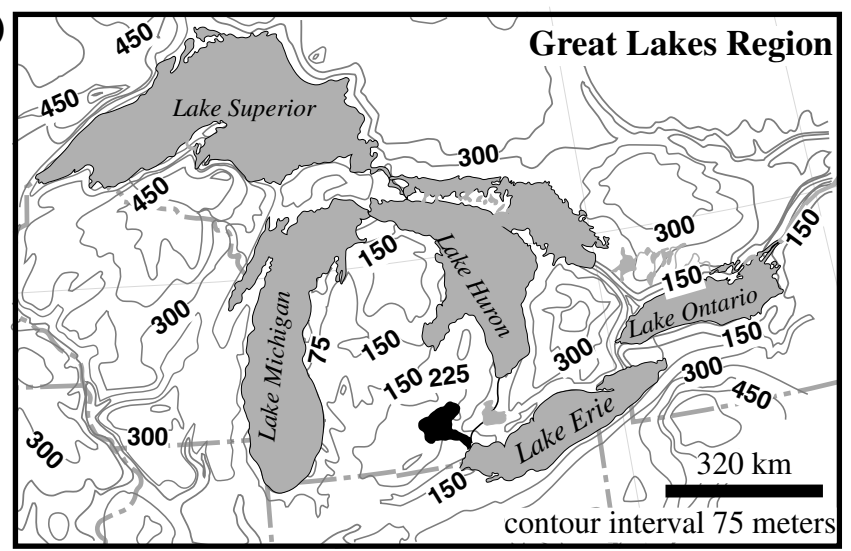

(b)

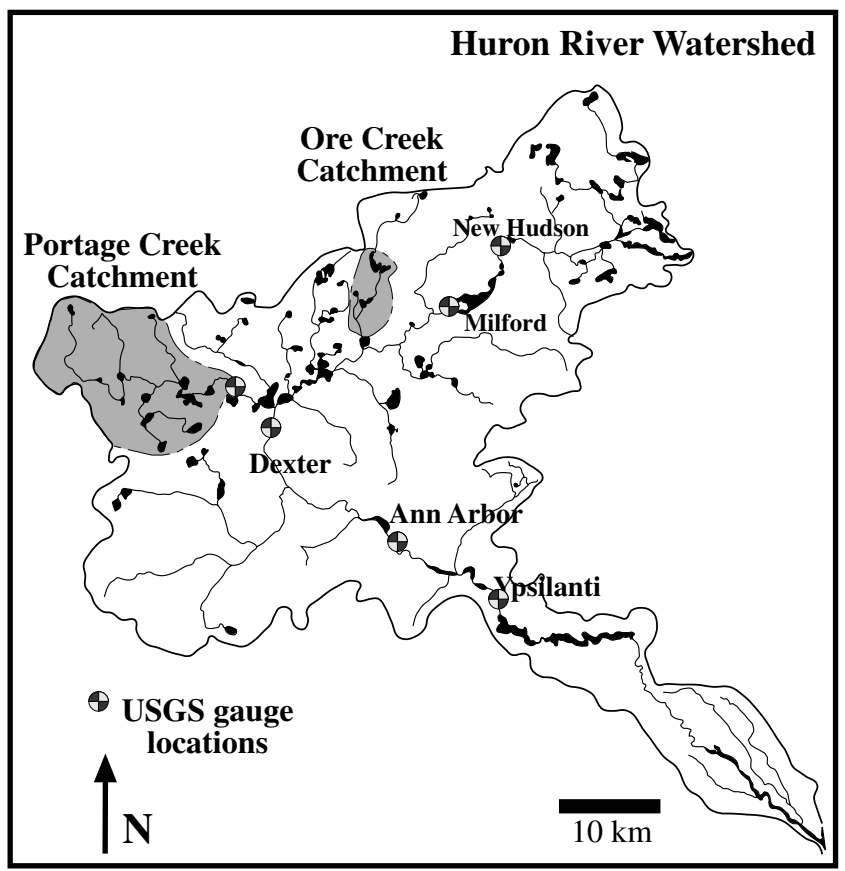

Figure 1. (a) A map of the mid-continent Pleistocene sediment thickness over bedrock. This map does not show the over all topography of the region, however due to the nature of the underlying bedrock, the surface topography is mainly controlled by the varying thickness of the glacial drift. The shaded area indicates the Huron River watershed in Michigan, USA. (b) The Huron River watershed. Portage and Ore Creek catchments are shaded in gray. The USGS gauge locations are indicated with the circle symbols.

River drainage is established on Wisconsinan age glacial drift deposits, with kettle and kame topography, up to $160 \mathrm{~m}$ thick composed of carbonate bearing sand, gravel and silt that mantle a low relief bedrock surface 
Table I. Huron River USGS Gauge data

\begin{tabular}{lcccccc}
\hline $\begin{array}{l}\text { Huron River } \\
\text { USGS gauge name }\end{array}$ & $\begin{array}{c}\text { Station } \\
(\text { number })\end{array}$ & $\begin{array}{c}\text { Drainage } \\
\text { area } \\
\left(\mathrm{km}^{2}\right)\end{array}$ & $\begin{array}{c}\text { Total } \\
\text { volume } \\
\left(10^{10} 1 / \text { year }\right)\end{array}$ & $\begin{array}{c}\text { Normalized } \\
\text { discharge } \\
\left(1 / \mathrm{km}^{2}-\mathrm{s}\right)\end{array}$ & $\begin{array}{c}\text { Data } \\
(\text { years })\end{array}$ & $\begin{array}{c}\text { Ave. } \\
\mathrm{HCO}_{3}^{-} \\
(\mathrm{meq} / 1)\end{array}$ \\
\hline At Milford, MI & 4170000 & 383 & 9.1 & 7.5 & 53 & 3.93 \\
Near New Hudson, MI & 4170500 & 342 & 10.3 & 9.6 & 53 & 3.63 \\
Near Dexter, MI & 4173000 & 1352 & 31.7 & 7.4 & 26 & 3.71 \\
At Ann Arbor, MI & 4174500 & 1888 & 40.5 & 6.8 & $87+$ & 3.85 \\
At Ypsilanti, MI & 4174800 & 2090 & 57.5 & 8.7 & 13 & 3.76 \\
\hline
\end{tabular}

Data source: NWISWeb, 2001.

(Farrand, 1982). The Huron River watershed is comprised of lakes and extensive wetlands, including marshes, bogs, and fens. This landscape structure is a result of ice and debris left behind after the retreat of the last glacial maximum in southern Michigan approximately 13,000 years ago.

The soils of the southeastern Lower Peninsula of Michigan began formation about 13,000 years ago and unaltered parent drift materials are typically encountered within 1-2 $\mathrm{m}$ of the surface. Soils are mainly alfisols, which form in temperate humid regions under deciduous forests (Brady and Weil, 1996). Clays within these soils are dominantly kaolinite making cation exchange capacities (CEC) relatively low.

The watershed has a drainage area above the city of Ann Arbor of $1,888 \mathrm{~km}^{2}$. The USGS has maintained multiple river discharge gauges in the Huron River watershed. The locations of the 5 main gauge sites with long-term data are shown in Figure $1 \mathrm{~b}$ and Table I summarizes site information, drainage area, and discharge statistics. Our study of the Huron watershed focused on two catchments, the Portage Creek $\left(205 \mathrm{~km}^{2}\right)$ and the Ore Creek $\left(86 \mathrm{~km}^{2}\right)$ drainages (Figures $1 \mathrm{~b}$ and $2 \mathrm{a}$ and $\mathrm{b}$ ). Portage Creek flows through a forested and agriculturally rich area that has less urban development than the remaining drainage area, including the Ore Creek region. These two catchments have well developed carbonate rich wetlands called fens which are common in the Pleistocene glaciated landscapes of the mid-continent of the United States (Almendinger and Leete, 1998a,b; Komor, 1994). The Portage Creek catchment (Figure 2b) has a fen (Figure 2c) located along Tiplady Rd., near Hell, Michigan $\left(\mathrm{W} 83^{\circ} 59^{\prime} 08^{\prime \prime}\right.$ and $\mathrm{N} 42^{\circ} 26^{\prime} 36^{\prime \prime}$ ). This fen has surface sediments consisting of both organic (peat) and inorganic low $\mathrm{Mg}$ calcite (marl) soils. The Ore Creek catchment (Figure 2a) has a fen located in the Brighton recreation area along Bauer Rd., near Brighton, Michigan (W83 $49^{\prime}$ and $\mathrm{N} 42^{\circ} 31^{\prime}$ $40^{\prime \prime}$ ). This fen has marl sediments below a thin surface cover (approximately $1 \mathrm{~cm}$ ) of organic matter. In both cases, the fens are associated with 


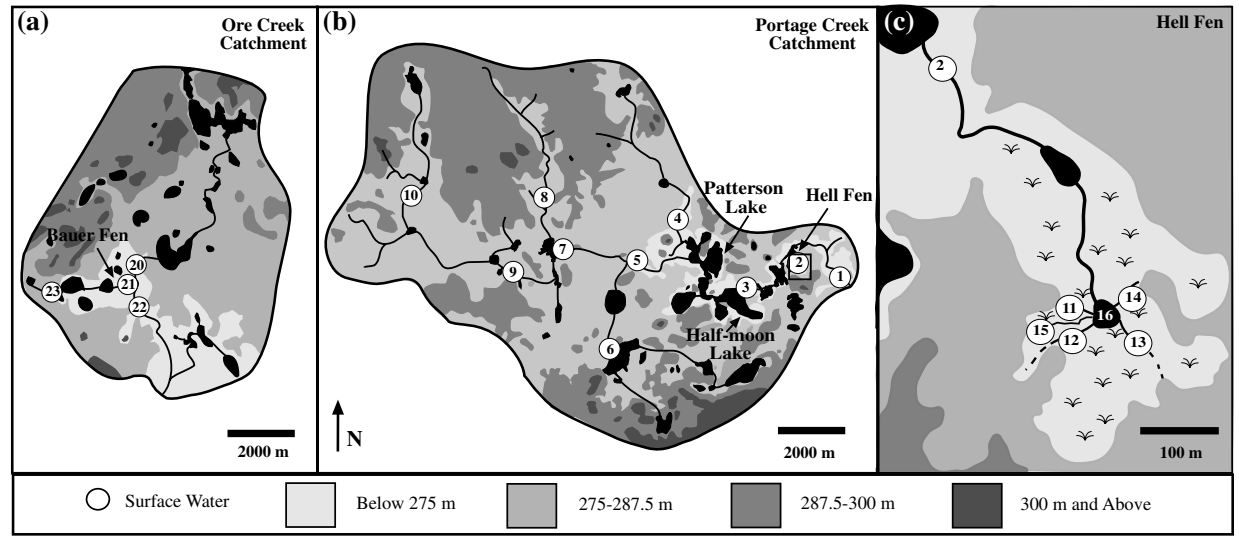

Figure 2. (a) Generalized topography map of the Ore Creek catchment. Topography is represented with darker to lighter shading as the elevation decreases. The locations of the sampling sites are indicated with circles and sample numbers on the maps. (b) Generalized topography map of the Portage Creek catchments. Lakes sampled in the study are indicated. The box on the Portage Creek drainage indicates the location of the Tiplady road fen that is shown in (c). (c) A schematic diagram of the drainage and topography for Hell fen on Tiplady road in the Portage Creek catchment. Sample sites and numbers are also indicated, note that sample number 2 is the same as in (b).

focused groundwater recharge from the topographically high areas surrounding the fen.

In addition to the fens, lakes form an important part of the drainage system in the Huron River watershed. In this study, two lakes, Halfmoon and Portage were sampled for water chemistry. Halfmoon Lake is the larger of the two with an average depth of $14 \mathrm{~m}$ and a volume of $13 \times 10^{6} \mathrm{~m}^{3}$, while Patterson Lake is $9 \mathrm{~m}$ deep and has a volume of $5.7 \times 10^{6} \mathrm{~m}^{3}$. Many of the lakes in the region have bottom sediments comprised of organic muck and carbonate mud, Halfmoon and Patterson Lakes are excellent examples of these marl lakes. Seepage lakes typically have high groundwater input to their basins (Dustin et al., 1986; Wachniew and Rozanski, 1997). Similar to fens, discharging groundwaters could degas in the lake basin and potentially precipitate calcium carbonate. Even more importantly, biologic processes of respiration and photosynthesis also can significantly modify the carbonate equilibria in lake waters. Both the fens and lakes are active sites of carbon transformation and would be expected to moderate to some degree the mass transport of inorganic carbon mobilized from soil zones to the main channel of the Huron River.

\subsection{SAMPLING PERIODS AND PROTOCOLS}

Surface water samples were collected, time and weather permitting, on a monthly basis over the course of 21 months from August 1999 to May 2001. 
Table II. Totals for Ann Arbor, MI (4174500)

\begin{tabular}{llcl}
\hline $\begin{array}{l}\text { 12 month: } \\
\text { Time period }\end{array}$ & $\begin{array}{l}\text { Discharge } \\
\text { Total } \\
\left(10^{10} 1 \text { per year }\right)\end{array}$ & $\begin{array}{l}\text { Rain } \\
\text { total } \\
(\mathrm{cm})\end{array}$ & $\begin{array}{l}\text { Snow depth } \\
\text { total } \\
(\mathrm{cm})\end{array}$ \\
\hline July 1998-June1999 & 31.3 & 97.6 & 171.7 \\
July 1999-June 2000: Year 1 & 22.9 & 85.7 & 109.2 \\
July 2000-June 2001: Year 2 & 59.4 & 116.0 & 181.9 \\
\hline
\end{tabular}

Data source: NOAA- National Climatic Data Center.

Sampling times were spread out to capture seasonality and the resulting changes in discharge, and are separated into 2 years of study, Year 1 (July 1999-June 2000) and Year 2 (July 2000-June 2001). The characteristics of Huron River discharge and climate data for the study time period are given in Table II. The USGS site 4174500 (Huron River @ Ann Arbor) is the only real time gauging site with data pertinent to the chemical and discharge mass balance of our study sites. Eighty-seven years of discharge data at Ann Arbor indicate an average value of $4.05 \times 10^{10} 1$ per year (see Table I). During the year previous and Year 1 of the study, the discharge was well below the annual average, at 3.1 and $2.3 \times 10^{10} 1$, respectively. In contrast, Year 2 of the study has a discharge well above the annual average at $5.9 \times 10^{10} 1$.

Surface water sampling locations were selected based on the relationship to confluences with the main stream, at points before and after the stream passed through a lake system, and with regard to the ease of obtaining the sample (see Figure $2 \mathrm{a}-\mathrm{c}$ ). In addition to these considerations, sample locations were also positioned upstream of large roads and developments to limit potential contamination from local runoff. Groundwater samples were collected from glacial drift aquifers, which comprise the vast majority of tapped aquifers in the Huron watershed (Twenter et al., 1976). Well depths varied from 16 to $60 \mathrm{~m}$ in depth below the surface and most were unconfined (e.g., no water wells with locally perched water tables were included). Full hydrogeological information on each groundwater sampling site (e.g., elevation, water level, location map) is available in Szramek et al., (2004), a related study of the sources and sinks of toxic levels of arsenic in glacial drift aquifer systems.

\subsection{FIELD MEASUREMENTS}

Temperature, conductivity, dissolved oxygen (DO), and $\mathrm{pH}$ measurements were made in the field. Temperature and DO were measured using a YSI model $58 \mathrm{~m}$ and a YSI 5239 DO probe with high sensitivity membrane, directly at the source, either in the stream or at the groundwater well head. 
Conductivity was measured using a Corning $316 \mathrm{~m}$ with a two point calibration 0 and $1413 \mu \mathrm{s}$, to provide a rapid geochemical reference point. Dissolved oxygen measurements were precise to $\pm 5 \%$ saturation and conductivity measurements to within $\pm 5 \%$.

A Corning 315 high sensitivity $\mathrm{pH}$ meter with an Orion Ross combination $\mathrm{pH}$ electrode calibrated with low ionic strength buffers of 4.1 and 6.97 (corrected for temperature) was used to measure $\mathrm{pH}$ in the field as close to the ambient water temperature as possible. Because $\mathrm{pH}$ is sensitive to degassing and warming, water samples were collected in a large volume, airtight container and $\mathrm{pH}$ was measured at least twice to verify electrode stability. The reproducibility of field $\mathrm{pH}$ determinations is $\pm 0.02 \mathrm{pH}$ units.

Sample aliquots collected for later chemical analysis in the laboratory were immediately passed through a $0.45 \mu$ m nylon filter into their respective bottles and kept refrigerated until analyzed. Acid washed HDPE bottles were used to collect anion and cation aliquots. DD water rinsed HDPE and glass bottles were used to collect alkalinity and dissolved organic carbon aliquots, respectively. Acid washed glass serum bottles capped with Teflon liners were used to store aliquots for dissolved inorganic carbon (DIC) analyses. These were poisoned in the field against biological activity using $\mathrm{CuCl}_{2}$ and were filled to the top with no headspace before capping. Sample aliquots for dissolved organic carbon (DOC) and cations were preserved in the field with concentrated $\mathrm{HCl}$ and $\mathrm{HNO}_{3}$ respectively. Sample aliquots for DIC.

\subsection{LABORATORY ANALYSIS}

Major element chemistry was measured by ICP-OES for cations and ion chromatography for anions. A Leeman Labs Inc. Plasma-Spec ICP-AES 2.5 was used to analyze for $\mathrm{Ca}, \mathrm{Mg}, \mathrm{Na}, \mathrm{K}, \mathrm{Sr}, \mathrm{Ba}, \mathrm{Mn}, \mathrm{Fe}, \mathrm{Zn}, \mathrm{Si}$, and $\mathrm{B}$ with a precision of $\pm 2 \%$ for major and $\pm 5 \%$ for minor elements. Anions $\left(\mathrm{Cl}^{-}\right.$, $\mathrm{SO}_{4}{ }^{2-}, \mathrm{NO}_{3}{ }^{-}, \mathrm{PO}_{4}{ }^{3-}, \mathrm{F}^{-}$, and $\mathrm{Br}^{-}$) were analyzed on a Dionex $4000 \mathrm{I}$ series ion chromatograph (IC) with an AS14 column with a precision of $\pm 2 \%$. $\mathrm{PO}_{4}{ }^{3-}, \mathrm{Br}^{-}$and $\mathrm{F}^{-}$were found to be consistently below detection (less than $1 \mu \mathrm{M})$.

Total alkalinity was measured by electrometric endpoint titration using a Radiometer TitraLab automated titration system with a TIM900 titration manager and ABU91 or ABU93 autoburette. Due to the given measurement precision $( \pm 0.01 \mathrm{meq} / \mathrm{kg})$, the $\mathrm{pH}$ range of the samples, and the ionic composition of the solutions, $\mathrm{HCO}_{3}^{-}$was calculated as equivalent to total alkalinity. Charge balance calculations were performed on water chemistry data to check for internal analytical consistency, using the relationship: 


$$
\mathrm{CB}=\frac{\sum \mathrm{c}_{\text {cations }}-\sum \mathrm{c}_{\text {anions }}}{\sum \mathrm{c}_{\text {cations }}+\sum \mathrm{c}_{\text {anions }}} \times 100,
$$

where $c$ is the concentration in charge equivalents/1 of solution, the data were always within $\pm 5 \%$.

The DIC contents of $30 \mathrm{ml}$ samples were analyzed on a UIC Coulometrics $\mathrm{CO}_{2}$ coulometer with a precision of $\pm 2 \%$. The measured DIC and titration alkalinity values of the samples agreed to within the precision of the two measurements, thereby supporting this assumption. The DOC contents were measured using a high-temperature platinum-catalyzed carbon analyzer via combustion followed by infrared detection of $\mathrm{CO}_{2}$ (Shimadzu TOC-5000A) with an uncertainty of $\pm 2 \%$.

\subsection{AQUEOUS SPECIATION AND CARBONATE MINERAL EQUILIBRIA}

Aqueous speciation and mineral saturation state modeling was conducted on the data using the USGS program Solmineq.88 (Kharaka et al., 1988). Major elements $\left(\mathrm{Ca}^{+2}, \mathrm{Mg}^{+2}, \mathrm{Na}^{+}, \mathrm{K}^{+}, \mathrm{Sr}^{+2}, \mathrm{Si}, \mathrm{Cl}^{-}, \mathrm{SO}_{4}{ }^{2+}, \mathrm{NO}_{3}{ }^{-}\right)$, alkalinity $\left(\mathrm{HCO}_{3}^{-}\right), \mathrm{pH}$ and temperature were input into the program. Calculated values for $p \mathrm{CO}_{2}$ and IAP/K calcite $(\Omega \mathrm{c})$ were obtained from the Solmineq.88 output. The error in the $p \mathrm{CO}_{2}$ values provided by Solmineq. 88 is related to the precision of the $\mathrm{pH}$. Given a precision of $\pm 0.02 \mathrm{pH}$ units and the uncertainty in the titration alkalinity, the uncertainty in the $p \mathrm{CO}_{2}$ is about $10 \%$. Errors in cation measurements and the precision in measuring the carbonate parameters (alkalinity, $\mathrm{pH}$ ) determine the error in the IAP $/ \mathrm{K}$ for calcite to be within $25 \%$.

The geochemical evolution of the saturation state of a typical groundwater by progressive $\mathrm{CO}_{2}$ degassing was also modeled, assuming no change in temperature after discharge and a constant alkalinity value. The initial groundwater modeled had the following geochemical parameter values: $T=$ $11.1{ }^{\circ} \mathrm{C}, \mathrm{pH} 7.61, \log \mathrm{pCO}_{2}=-2.15 \mathrm{~atm} ., \mathrm{Ca}^{+2}=1.79 \mathrm{mM}, \mathrm{Mg}^{+2}=0.93$ $\mathrm{mM}$, Alk $=5.39 \mathrm{meq} / 1, \mathrm{Na}^{+}=1.02 \mathrm{mM}, \mathrm{Cl}^{-}=0.69 \mathrm{mM}$, and $\mathrm{SO}_{4}{ }^{-2}=$ $0.23 \mathrm{mM}$. Speciation under the new $p \mathrm{CO}_{2}$ conditions was calculated using the $\mathrm{CO}_{2}$ saturation option of Solmineq.88 and three different $\log \mathrm{pCO}_{2}$ values, $-2.5,-3.0$ and -3.5 atm.

\subsection{DATA RETRIEVAL FROM THE USGS STREAM DATABASE}

The five USGS stream gauge sites in the Huron River watershed listed in Table I were used in this data analysis. Historical discharge and chemical databases were downloaded from USGS National Water Information System (NWISWeb, 2001). The Huron River@ Milford 
(4170000), the HR near New Hudson (4170500), the HR near Dexter (4173000) and the HR @ Ypsilanti (4174800) all have historical discharge (usually collected on a daily basis), but much more limited sampling for chemical analyses (typically 1 sample per year). Chemical data available varied in the number of samples and the solutes reported The Huron River@Ann Arbor (4174500) is the only site with discharge data available from our the study time period, but no chemical data were gathered at this site. Data reported as total dissolved were used for all solutes, except alkalinity. Alkalinity is mainly reported as $\mathrm{CaCO}_{3}, \mathrm{HCO}_{3}^{-}$and as acid neutralizing capacity (ANC) and all were converted to $\mathrm{HCO}_{3}^{-}$alkalinity in meq/l.

Two of our routine field sampling sites (Portage at Tiplady, Site 1; Huron River near Dexter) coincided with USGS historical gauges (sites 4172500 and 4173000 , respectively). Both of these sites have been decommissioned. However, because historical discharge data were taken concurrently at these two sites with that from the functioning gauge site in Ann Arbor (4174500), interpolation of relative discharge proportions at each site was used to arrive at discharge values. This involved calculating the ratio of the annual discharge values from each site and normalizing them to drainage area (see Table 1). The ratios were remarkably constant, with estimated discharges $\pm 10 \%$ of observed values. This is supported by the relatively constant area normalized discharge data for each segment of the Huron River drainage shown in Table I.

\section{Results}

\subsection{ELEMENTAL GEOCHEMISTRY}

A complete geochemical data set of field, laboratory and calculated geochemical parameters is presented in Tables III-VII, including a subset of data previously shown in Szramek et al. (2004) for ease of comparison and completeness. Table III is divided by type of sample: (a) groundwater, (b) lake, (c) Huron River, (d) stream, and (e) fen. The surface water samples are represented in Tables and Figures in terms of Years 1 and 2 of the study period because of the different geochemical patterns observed for the low discharge Year 1 vs. the higher discharge Year 2 (Table II). Surface water temperatures range from 4 to $30^{\circ} \mathrm{C}$, while groundwaters are much more uniform at about $1{ }^{\circ} \mathrm{C}$. Minor element data for potassium and silica are not presented, as they do not contribute to charge balance significantly and are not involved with the major geochemical processes addressed here.

The Fe and $\mathrm{Mn}$ concentrations are presented as they differ significantly between ground, surface and lake waters. Fe and Mn concentrations for the 


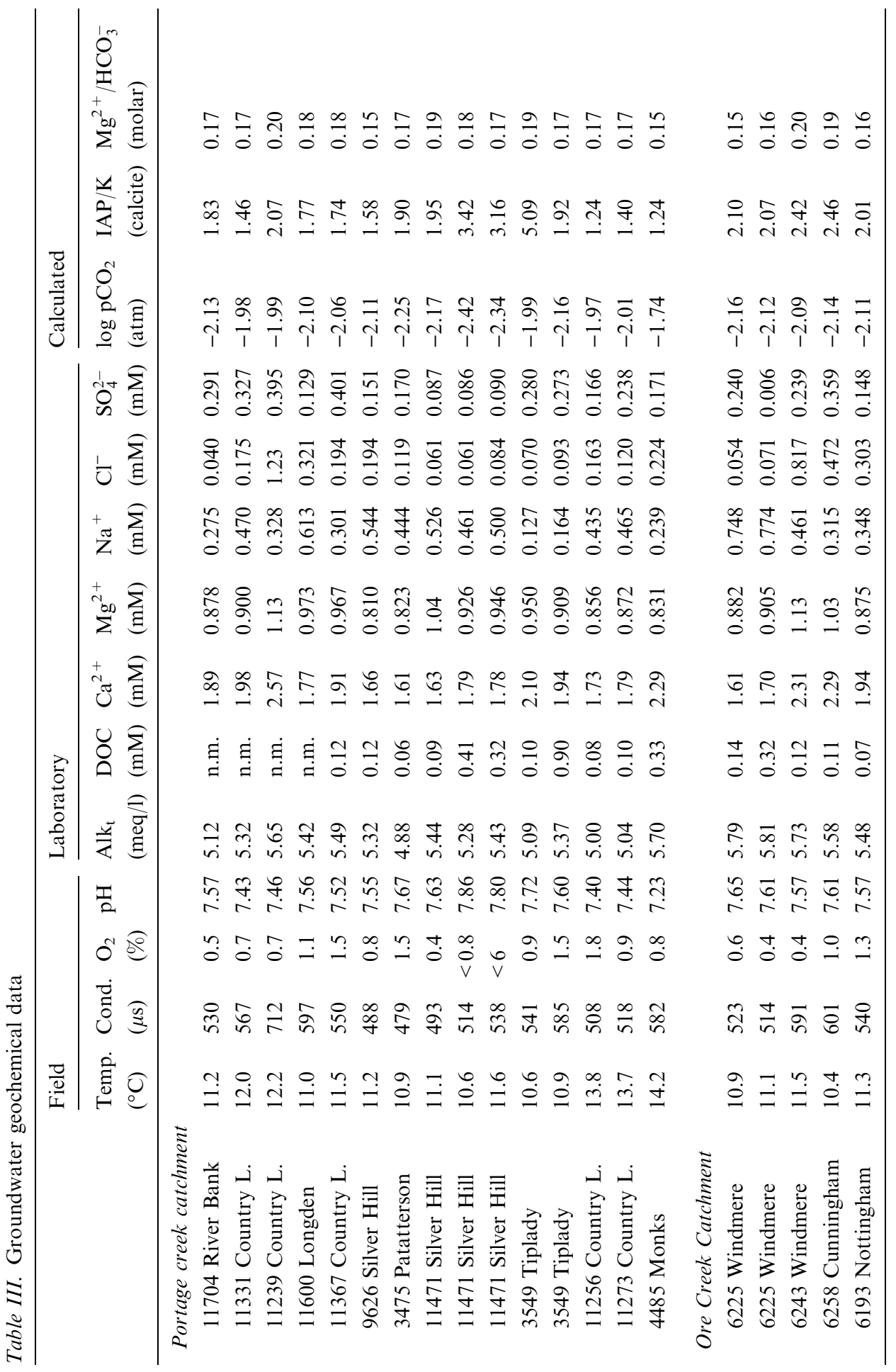




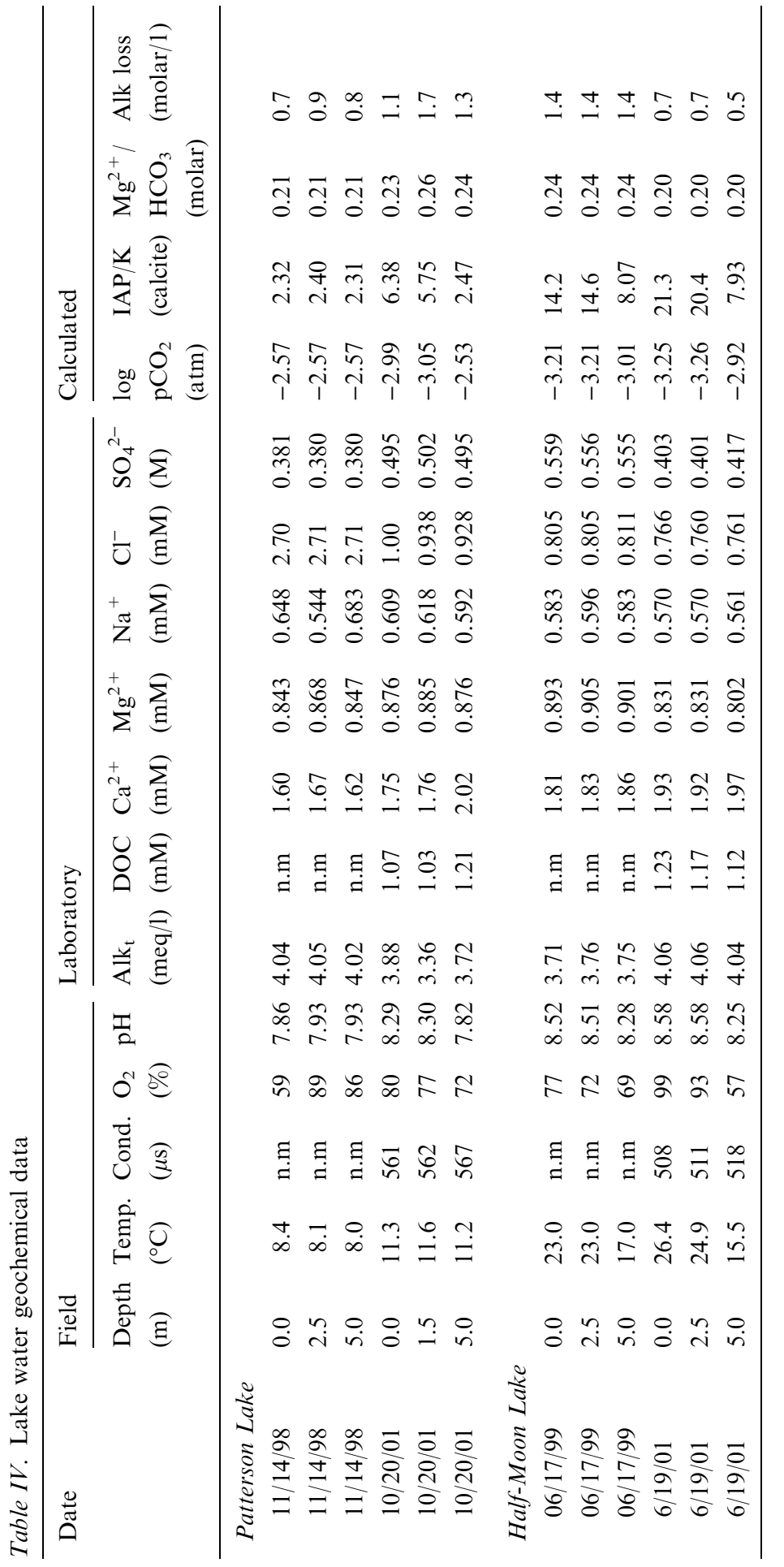




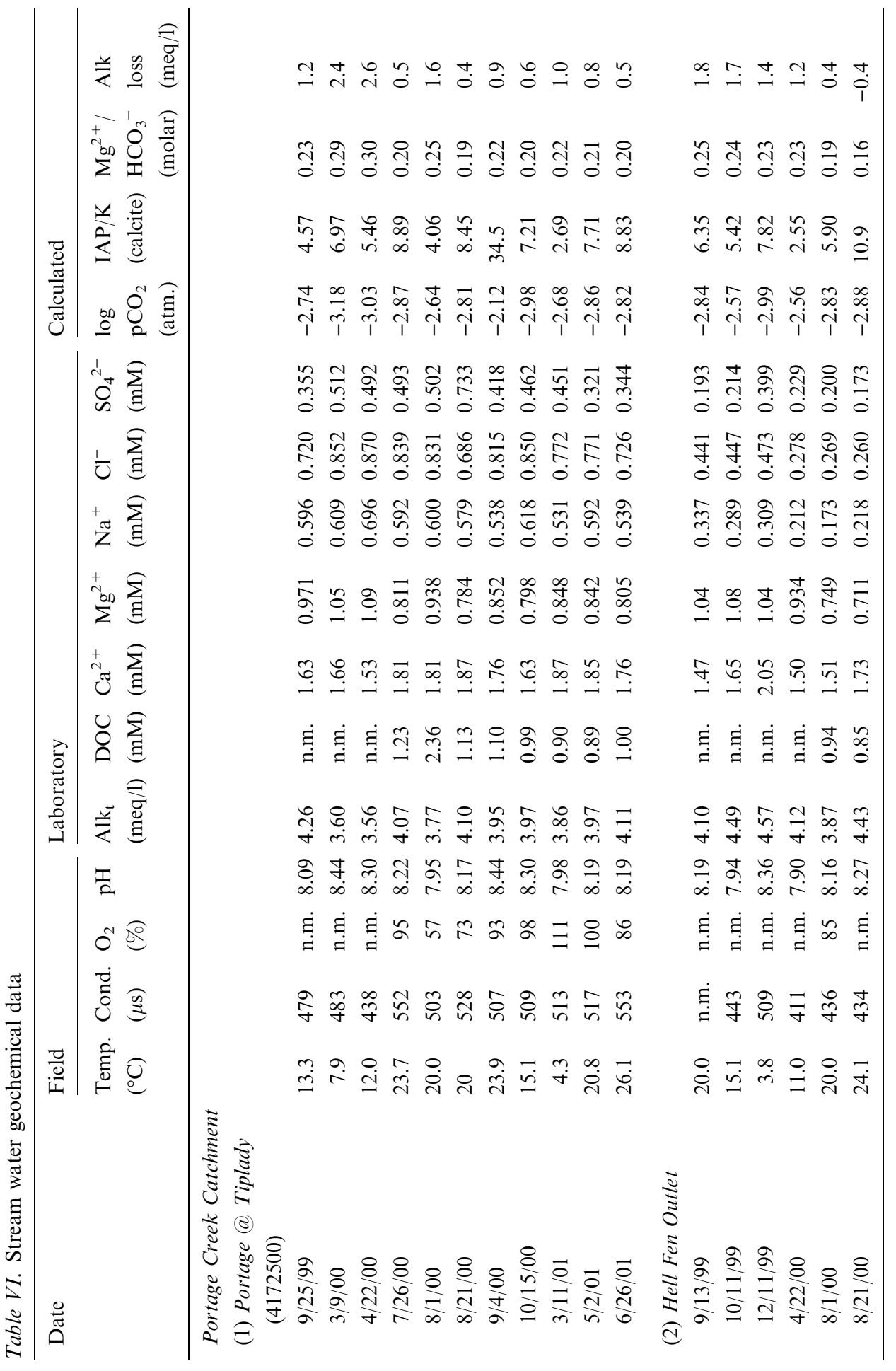




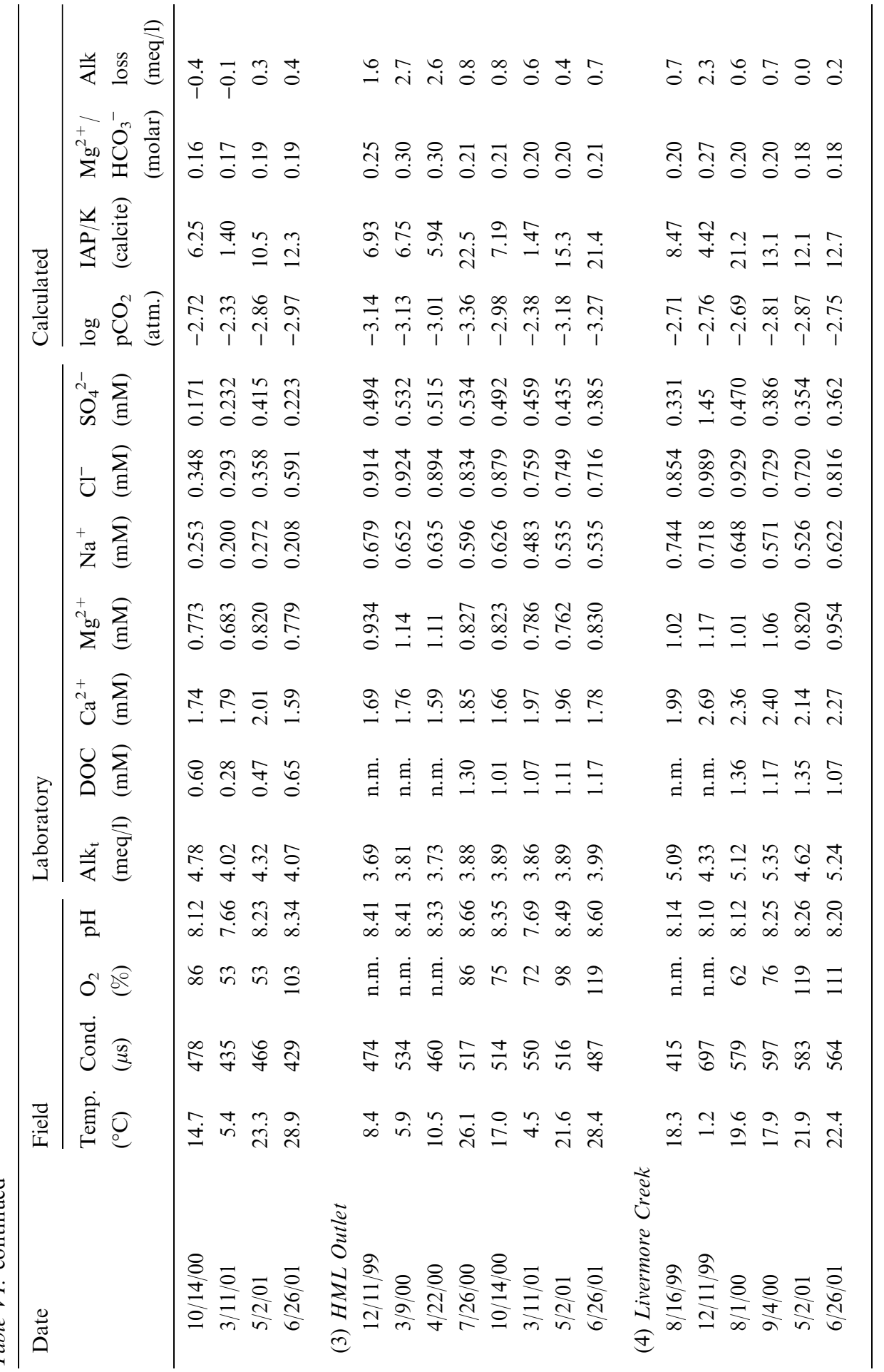




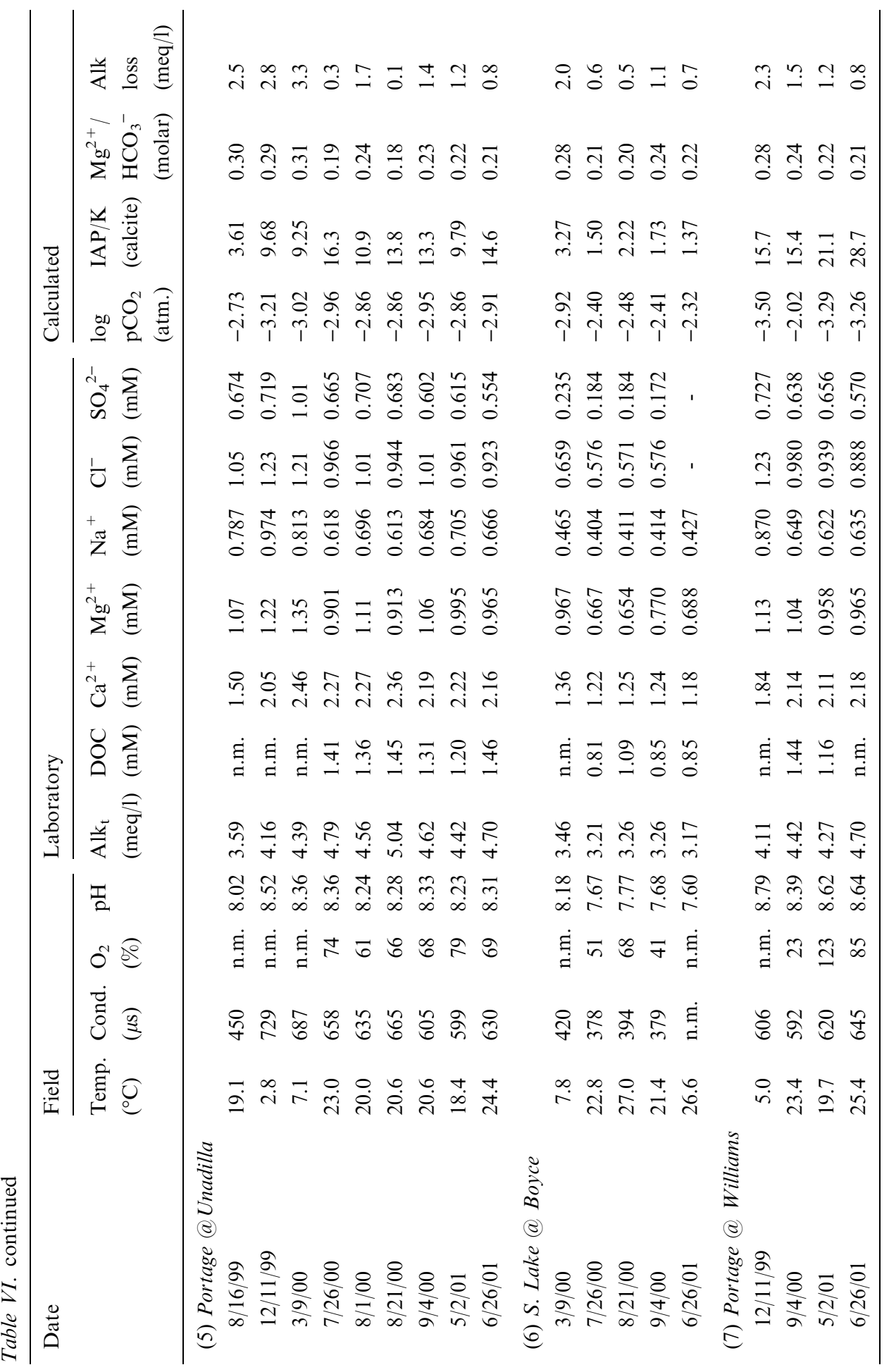




\begin{tabular}{|c|c|c|c|c|c|}
\hline & 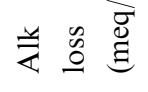 & $n=\stackrel{\infty}{n}: 0$ & 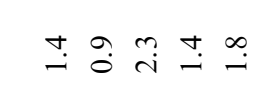 & 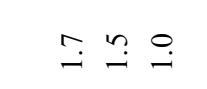 & o: \\
\hline & 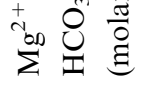 & 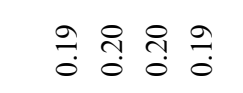 & 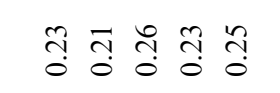 & त̂ં & $\stackrel{\infty}{\circ}$ กิ \\
\hline$\vec{\Psi}$ & 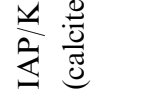 & 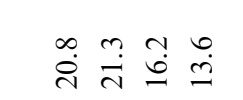 & 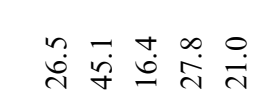 & $\stackrel{\hat{0}}{\hat{i}} \stackrel{0}{a}$ & $\begin{array}{ll}5 & 0 \\
i & \infty \\
i & 0\end{array}$ \\
\hline 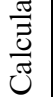 & on & 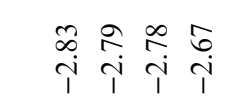 & 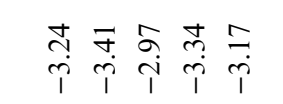 & $\begin{array}{lll}\infty & 0 & 0 \\
\infty & + & 0 \\
i & i & i \\
i\end{array}$ & $\stackrel{\sim}{\hat{i}} \underset{i}{i}$ \\
\hline & $\begin{array}{l}1 \\
\sim_{+}^{+} \\
O_{n}^{+}\end{array}$ & 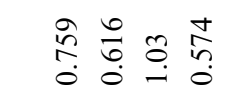 & 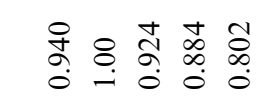 & 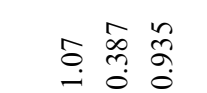 & 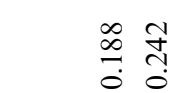 \\
\hline & ठ & 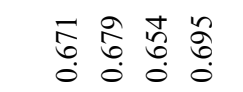 & 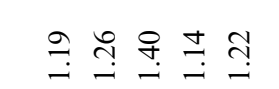 & 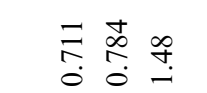 & 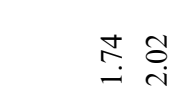 \\
\hline & 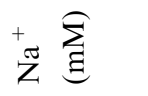 & 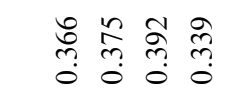 & 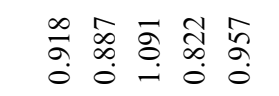 & $\begin{array}{c}\text { aे } \\
\text { ते } \\
0\end{array}$ & $\stackrel{\overbrace{}}{\oplus}$ \\
\hline & $\stackrel{+}{\infty}_{\sum^{\infty}} \sum^{\text {ह }}$ & તุ & 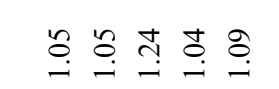 & ñ & 官 \\
\hline & $\stackrel{+}{\text { N }}$ & 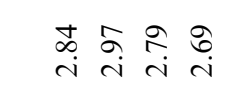 & 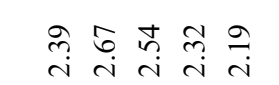 & 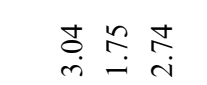 & $\bar{m} \stackrel{n}{n}$ \\
\hline $\overrightarrow{0}$ & ○ & $\stackrel{ }{\stackrel{ }{i}=}$ & 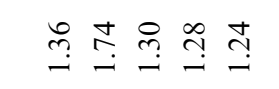 & 离 ત̣ & $\stackrel{\infty}{?} \stackrel{q}{0}$ \\
\hline 总 & 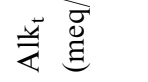 & 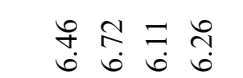 & 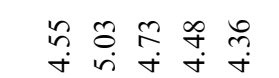 & 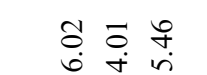 & 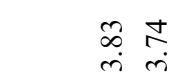 \\
\hline & $\frac{\pi}{2}$ & 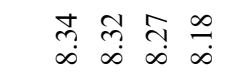 & 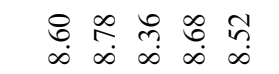 & 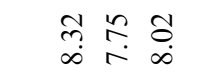 & 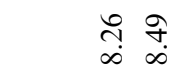 \\
\hline & $0 \widehat{S}$ & $\alpha \curvearrowright \& \infty$ & 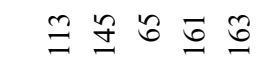 & $\underset{g}{g}$ & $\triangleright \varnothing$ \\
\hline & 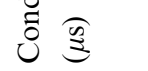 & 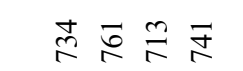 & 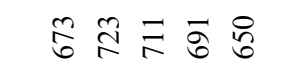 & ते जे ఫ્ठ & 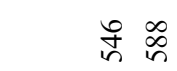 \\
\hline & 產 ठ & 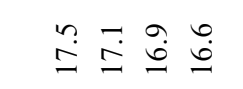 & 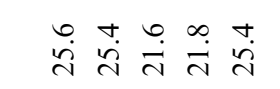 & 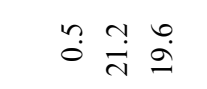 & $\begin{array}{l}\ddot{n} \\
\ddot{n}\end{array}$ \\
\hline$\stackrel{\mathscr{0}}{\tilde{I}}$ & & 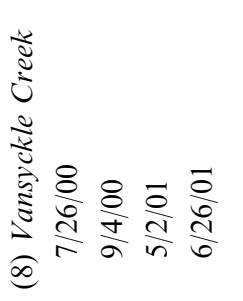 & 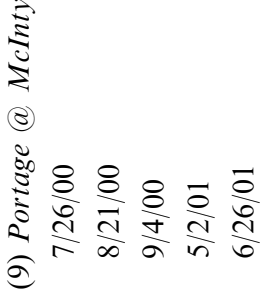 & 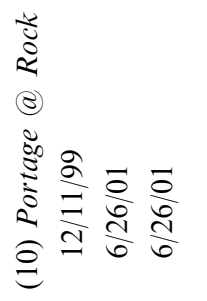 & 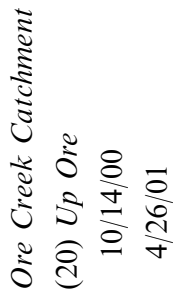 \\
\hline
\end{tabular}




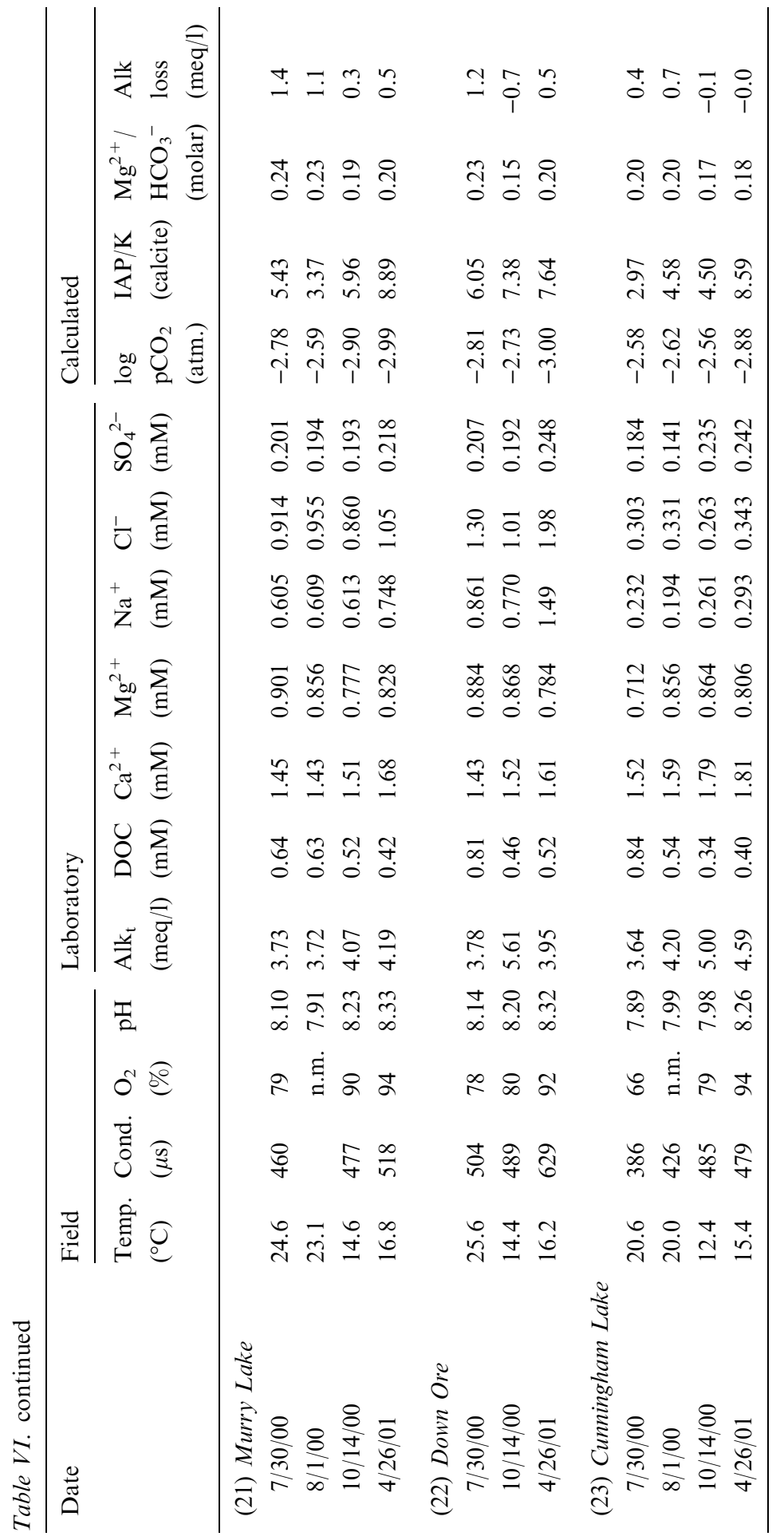




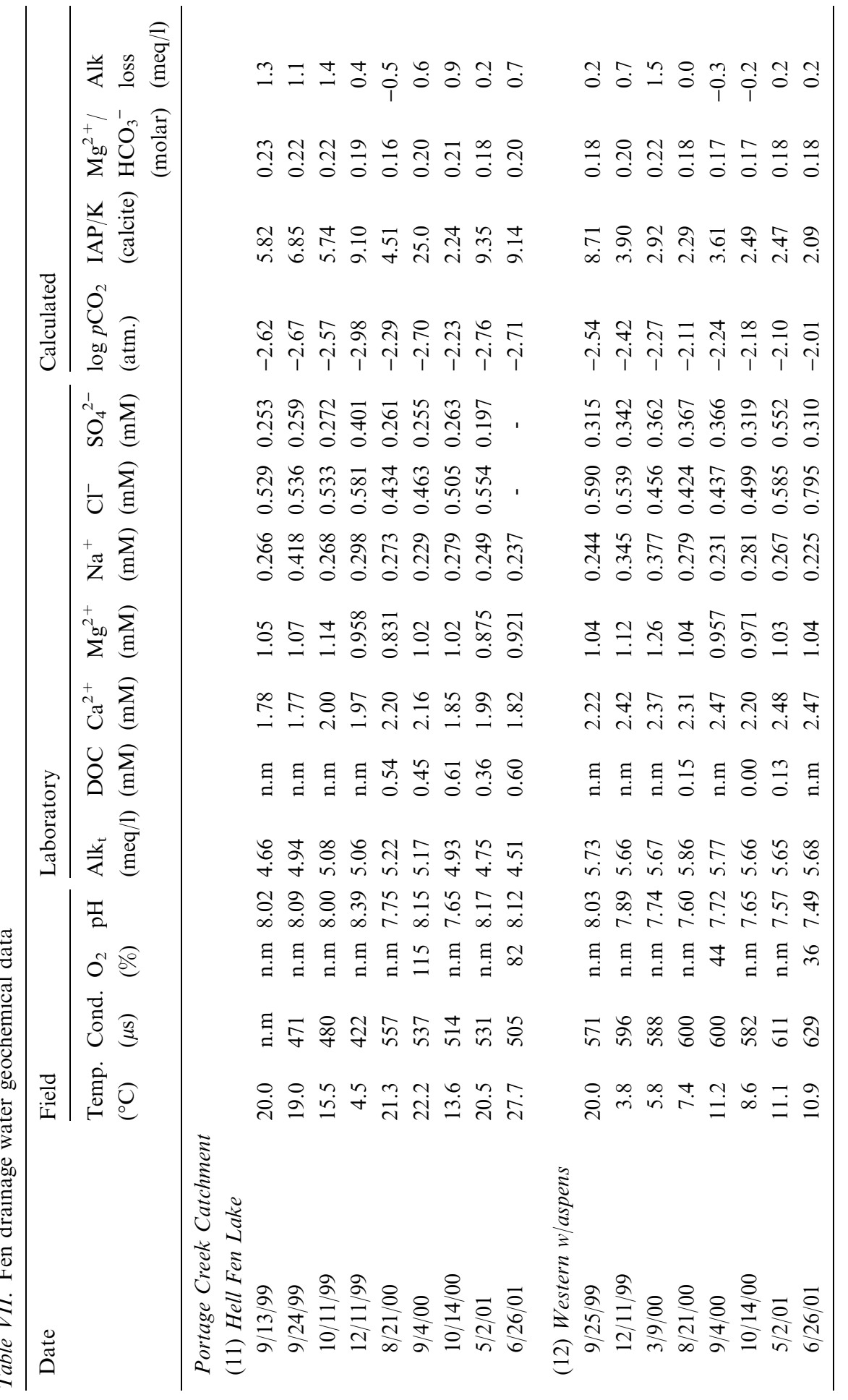




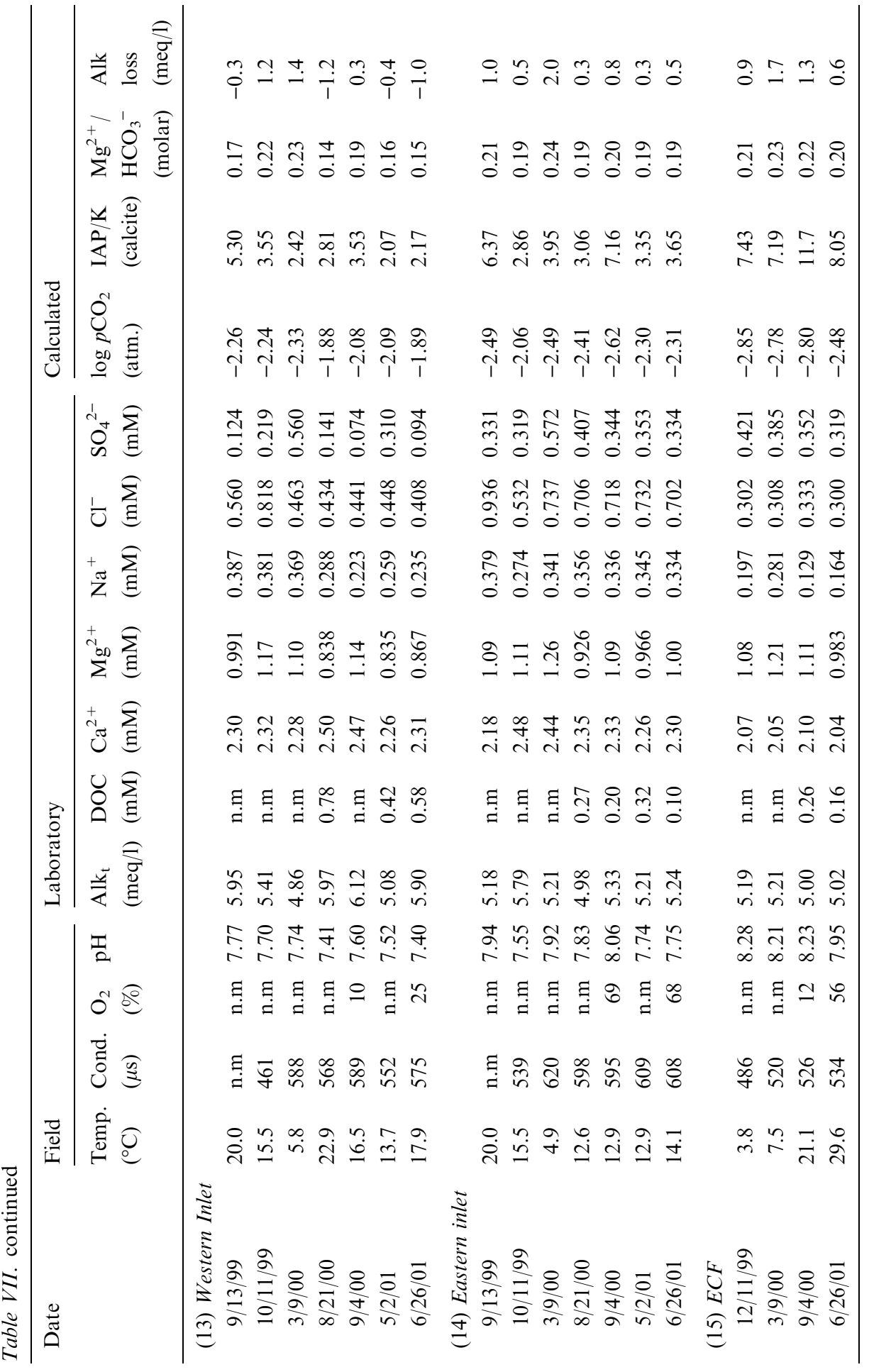




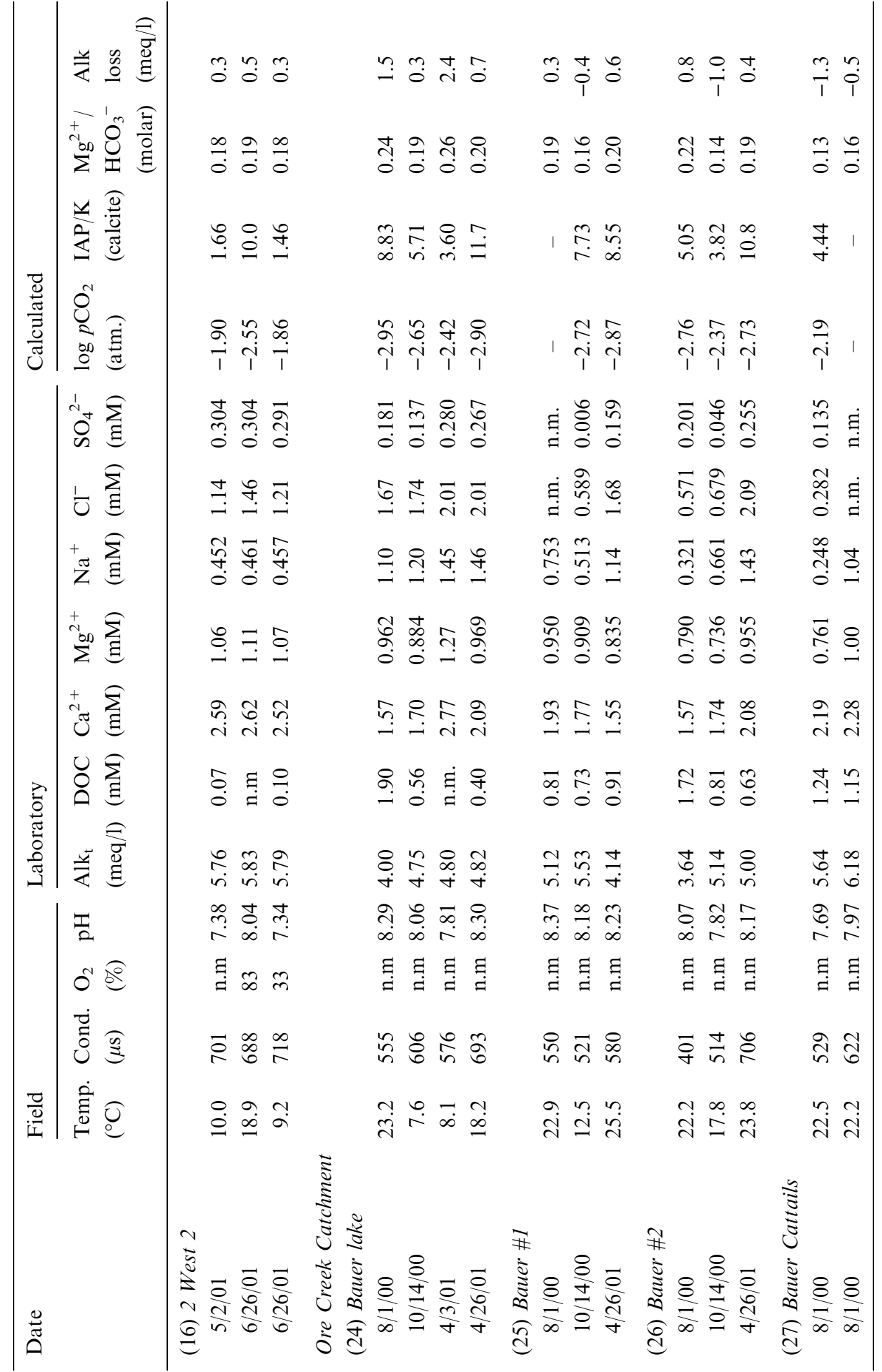



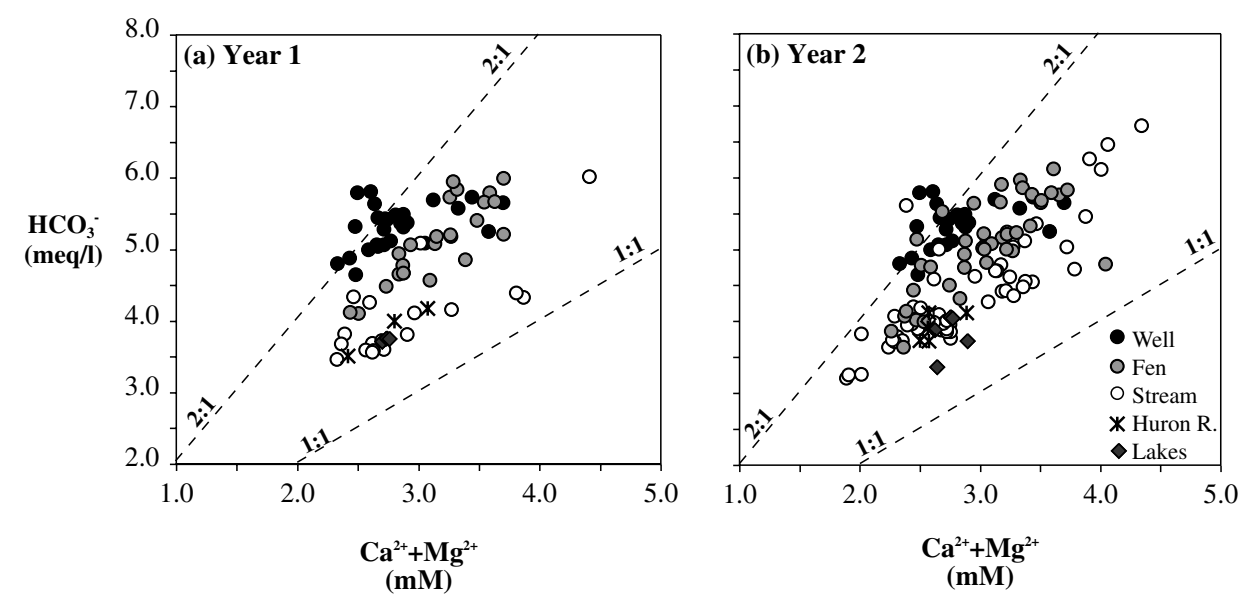

Figure 3. $\mathrm{HCO}_{3}^{-}$vs. $\mathrm{Ca}^{2+}+\mathrm{Mg}^{2+}$ for both ground and surface waters during Years 1 and 2 for the Portage and Ore creek catchments in the Huron River Watershed. Groundwaters fall around the $2\left(\mathrm{Ca}^{2+}+\mathrm{Mg}^{2+}\right)=\mathrm{HCO}_{3}^{-}$line, indicating the water chemistry is controlled by carbonate mineral dissolution. The surface waters fall below this line, indicating $\mathrm{HCO}_{3}^{-}$loss relative to $\mathrm{Ca}^{2+}+\mathrm{Mg}^{2+}$.

surface, fen and lake samples are very low, usually less than $5 \mu \mathrm{M}$ for Fe and $3 \mu \mathrm{M}$ for $\mathrm{Mn}$. These samples are all in contact with the atmosphere, which would cause removal of most of the $\mathrm{Mn}$ and all of the $\mathrm{Fe}$ through the formation of hydroxides. Arsenic is also shown to be present in the groundwaters, however arsenic is absent from the surface waters due to its incorporation into the hydroxides (Szramek et al., 2004). The groundwater samples are approximately an order of magnitude higher in Fe $(\sim 30 \mu \mathrm{m})$ and within the same range as other waters for $\mathrm{Mn}$. The trend of higher dissolved $\mathrm{Fe}$ and $\mathrm{Mn}$ in the groundwaters relative to the surface waters is consistent with the very low dissolved oxygen concentrations and Fe mobilization from buried paleosoil zones in the drift deposits (Szramek et al., 2004).

In general all sample types are predominantly $\mathrm{Ca}^{2+}-\mathrm{Mg}^{2+}-\mathrm{HCO}_{3}^{-}$waters (Figure $3 \mathrm{a}$ and $\mathrm{b}$ ), where $\mathrm{HCO}_{3}^{-}$is the single most abundant dissolved species. The stoichiometric relationship between $\mathrm{HCO}_{3}^{-}$and $\mathrm{Ca}^{2+}+\mathrm{Mg}^{2+}$ in the samples from our study indicates that the waters are essentially a result of carbonate dissolution and groundwaters fall around the $2: 1$ line of $2\left(\mathrm{Ca}^{2+}+\right.$ $\mathrm{Mg}^{2+}$ ) $=\mathrm{HCO}_{3}^{-}$(Figure 3a and b). Given that that groundwater is the major water source to streams during most of the year, surface, fen and lake waters all appear to have lost $\mathrm{HCO}_{3}^{-}$or gained divalent cations relative the groundwater source.

The relationships between $\mathrm{Na}^{+}$and $\mathrm{Cl}^{-}$concentrations shown in Figure $4 \mathrm{a}$ and $\mathrm{b}$ explain this excess $\mathrm{Ca}^{2+} \cdot \mathrm{Na}^{+}$and $\mathrm{Cl}^{-}$concentrations increase due to anthropogenic salt inputs. These salts include about 20,000 lbs of halite from the Morton Company salt mine near Detroit 

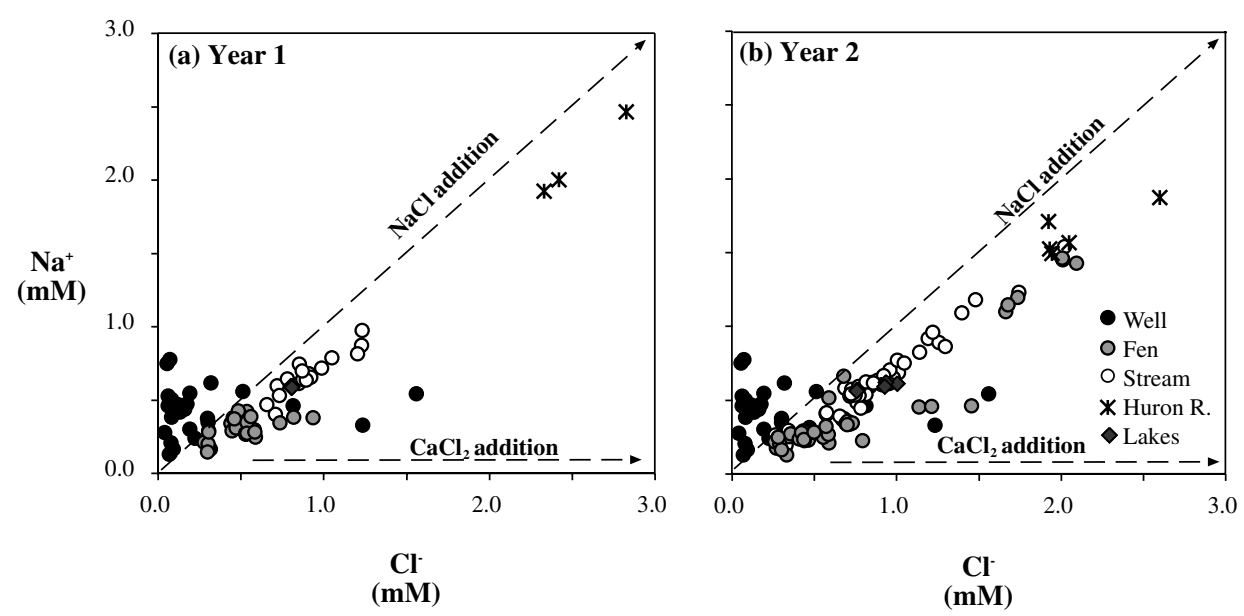

Figure 4. $\mathrm{Na}^{+}$vs. $\mathrm{Cl}^{-}$for Years 1 and 2 of the Portage and Ore Creek catchment ground and surface waters. A 1:1 line indicates the stoichiometric dissolution of halite $(\mathrm{NaCl})$. The groundwaters fall above the 1:1 line with higher concentrations of $\mathrm{Na}^{+}$relative to $\mathrm{Cl}^{-}$. The surface waters fall below the 1:1 line indicating that the additional $\mathrm{Cl}^{-}$has multiple sources, including $\mathrm{NaCl}$ and $\mathrm{CaCl}_{2}$. A line indicating the direction water samples would move from the 1:1 line with the addition of $\mathrm{CaCl}_{2}$ is shown.

Michigan added each year by the Washtenaw County transportation department for deicing roads (Mulcahy, 2003). The Portage Creek catchment (Figure 4a) has a few groundwaters with higher than average $\mathrm{Na}^{+}-\mathrm{Cl}^{-}$concentrations, but in general the groundwaters are dilute in comparison and typically have a molar excess of $\mathrm{Na}^{+}$increasing the $\mathrm{Na}^{+} / \mathrm{Cl}^{-}$ratios in these groundwaters. Since these are all shallow groundwaters contained in permeable glacial drift material rich in aluminosilicates, the $\mathrm{Na}^{+}$excess likely is derived from plagioclase feldspar dissolution. The surface waters on the other hand range from more dilute waters to relatively high $\mathrm{Na}^{+}$and $\mathrm{Cl}^{-}$concentrations at $3 \mathrm{mM}$ each. In most cases the surface, fen and lake waters do not have a 1:1 relationship between $\mathrm{Na}^{+}$and $\mathrm{Cl}^{-}$; this would be expected if halite dissolution were adding all the excess $\mathrm{Na}^{+}$and $\mathrm{Cl}^{-}$in the water.

Along with $\mathrm{NaCl}$ (halite), $\mathrm{CaCl}_{2}$ (basinal and man-made brines) is also being added to deice residences and roads in the winter and to assist dust control on dirt roads in the summer months. Gypsum $\left(\mathrm{CaSO}_{4}\right)$ dissolution or sulfide oxidation processes can also contribute excess calcium, but since sulfate concentrations of $90 \%$ of the surface water samples are below 0.5 $\mathrm{mM}$, these processes make a relatively small contribution to the overall excess calcium budget relative to $\mathrm{CaCl}_{2}$ salts (see Tables III-VII). 


\subsection{GENERAL PATTERNS OF ELEMENTAL CHEMISTRY AT USGS GAUGE STATIONS}

Historical area-normalized discharge values and chemical data $\left(\mathrm{HCO}_{3}^{-}\right.$, $\mathrm{Ca}^{2+}+\mathrm{Mg}^{2+}$, and $\mathrm{Cl}^{-}$concentrations) for four USGS gauging stations are shown in Figure $5 \mathrm{a}-\mathrm{c}$. Although the historical data available are not extensive, the historical data are quite similar to the values observed in our study for the Huron River near Dexter. There is no systematic difference among the four sites for the carbonate-related parameters. In contrast, chloride concentrations vary widely among sites due to differences in proximity to developed highways and residential areas where road salting is common.

The $\mathrm{Cl}^{-}$values appear to decrease with increasing discharge value at most of the gauge sites. However, periods of elevated discharge do not significantly differ in $\mathrm{Ca}^{2+}+\mathrm{Mg}^{2+}$ or $\mathrm{HCO}_{3}^{-}$values at any of the four gauging sites, except the extreme discharges at the Ypsilanti gauge where the values decrease. Because the soils developed on the glacial drift in the Huron Watershed are very rich in carbonate minerals, runoff from snowmelt and/or storm events is very similar to the overall chemical stoichiometry observed in shallow groundwaters (compare to Figure 3 values from the present study).

Alkalinity and discharge relationships for the four sites suggest that the lowest discharge periods also have some of the lower alkalinity concentrations. The highest alkalinity values are observed during discharge conditions near the long term average values (see Table I) for each gauging site. Significantly, watersheds developed on carbonate landscapes in Europe (Seine, Loire Rivers) have similar patterns of alkalinity concentration with discharge, with minima occurring at low and high discharge values (Grosbois et al., 2000; Roy et al., 1999).

\subsection{NORMALIZATION OF WATER CHEMISTRY TO GROUNDWATER $\mathrm{Mg}^{2+} / \mathrm{HCO}_{3}^{-}$VALUE}

Previous studies have examined carbonate mass balances in carbonate precipitating springs and streams, using the stoichiometric loss of $\mathrm{Ca}^{2+}$ and $\mathrm{HCO}_{3}^{-}$(Drysdale et al., 2002; Herman and Lorah, 1987; Jacobson and Usdowski, 1975; Lorah and Herman, 1988; Zaihua et al., 1995). This approach allows the amount of carbonate dissolved or precipitated to be evaluated independently of dilution effects. However, in the Huron watershed, $\mathrm{Ca}^{2+}$ has another source, anthropogenic $\mathrm{CaCl}_{2}$, so $\mathrm{Ca}^{2+}$ concentrations in combination with alkalinity values cannot be used to arrive at accurate estimates of amounts of carbonate precipitation.

Although the carbonate related divalent cation $\mathrm{Sr}^{2+}$ has proven useful as a $\mathrm{Ca}^{2+}$ tracer in stream waters (e.g. Blum et al., 1998; Jacobson et al., 2002), the 

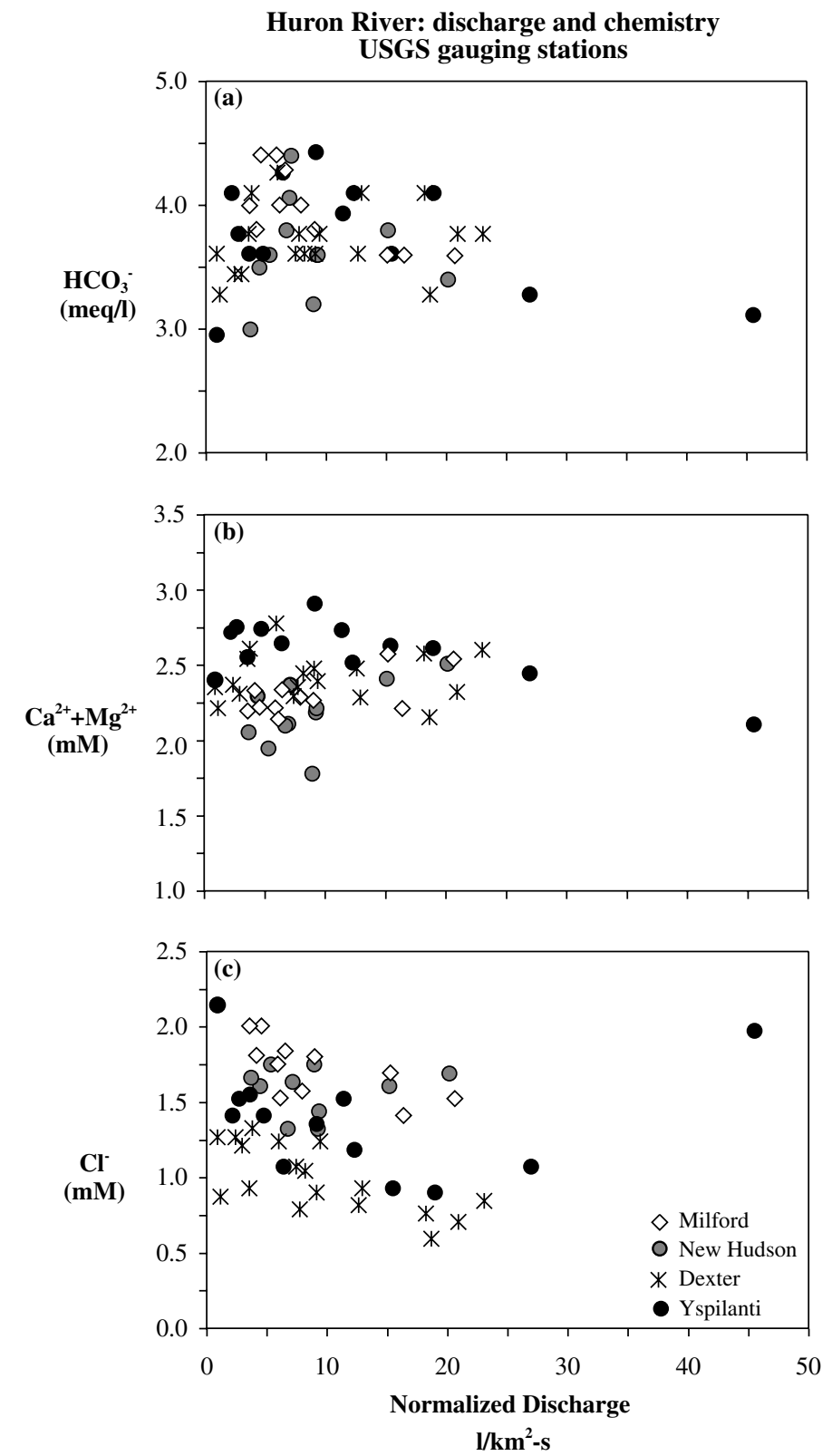

Figure 5. Discharge and chemistry $\left(\mathrm{HCO}_{3}^{-}\right.$(meq/l), $\mathrm{Ca}^{2+}+\mathrm{Mg}^{2+}(\mathrm{mM})$, and $\left.\mathrm{Cl}^{-}(\mathrm{mM})\right)$ relations for 4 USGS gauge sites on the Huron River located in Figure 1. Table I reports the station \# and drainage area for each location.

basinal brine-derived $\mathrm{CaCl}_{2}$ salts from the Michigan Basin have a $\mathrm{Sr}^{2+} / \mathrm{Ca}^{2+}$ ratio almost 1000 times higher than in our groundwaters (see McIntosh et al., GSA Bull, 2004, in press). To better quantify the amount of carbonate back 
precipitation, a "conservative" element derived only from carbonate mineral dissolution with no significant geochemical sink is required.

The $\mathrm{Mg}^{2+}$ in the waters from the Huron River watershed is derived largely from the dissolution of dolomite commonly present in the glacial drift. The $\mathrm{Mg}^{2+} / \mathrm{Ca}^{2+}$ of the groundwaters is on average $0.49 \pm 0.05$ molar ratio, indicating that approximately one mole of calcite dissolves for every mole of dolomite. Once released from dolomite, the $\mathrm{Mg}^{2+}$ has no other significant sink as the calcites forming in the fens and lakes have $\mathrm{Mg}^{2+}$ contents between 2 and $5 \mathrm{~mol} \%$ (Komor, 1994), consistent with what is known of the partitioning of $\mathrm{Mg}^{2+}$ into calcites (e.g. Morse and Mackenzie, 1990). Normalizing losses of alkalinity to the $\mathrm{Mg}^{2+} / \mathrm{HCO}_{3}^{-}$ratio eliminates the complications presented by rainwater dilution or evapo-concentration.

Figure $6 \mathrm{a}$ and $\mathrm{b}$ presents the $\mathrm{Mg}^{2+}$ to $\mathrm{HCO}_{3}^{-}$ratios for the various water types. The average groundwater ratio of $\mathrm{Mg}^{2+}$ to $\mathrm{HCO}_{3}^{-}$is 0.18 for these two areas. The groundwater $\mathrm{Mg}^{2+}$ and $\mathrm{HCO}_{3}^{-}$relationships for watersheds in Michigan, including the Huron River water are detailed in Szramek et al. (GSA Bulletin in prep.). $\mathrm{Mg}^{2+} / \mathrm{HCO}_{3}^{-}$values evolve progressively away from the groundwater, increasing in the surface, lake and fen samples. Note that most of the change in surface water chemistry takes place in the $\mathrm{HCO}_{3}^{-}$ concentration while $\mathrm{Mg}^{2+}$ concentrations tend to be similar to or greater than the original groundwater values. Year 1 shows a more pronounced increase as a result of the preferential loss of $\mathrm{HCO}_{3}^{-}$relative to $\mathrm{Mg}^{2}$ than does Year 2. By the time the waters from the Portage and Ore creek drainages enter into the main stem of the Huron River, $\mathrm{HCO}_{3}^{-}$loss has already occurred.

\subsection{VARIATION OF CARBONATE SATURATION PARAMETERS WITH MAJOR ELEMENTAL CHEMISTRY}

Carbonate system parameters further constrain the conditions required for carbonate precipitation. As the $\mathrm{CO}_{2}$ partial pressure increases, carbonate mineral solubility in pure water systems also increases (e.g. Drever, 1997; Langmuir, 1997; Morse and Mackenzie, 1990). Typically, ground and soil waters have $p \mathrm{CO}_{2}$ 's $10-100$ times the atmospheric $p \mathrm{CO}_{2}$ of $10^{-3.5} \mathrm{~atm}$. The relationships between calcite saturation state, alkalinity, $\mathrm{Ca}^{2+}$, and $p \mathrm{CO}_{2}$ can be shown directly by the following equation for calcite dissolution:

$$
\mathrm{CaCO}_{3}+\mathrm{CO}_{2}+\mathrm{H}_{2} \mathrm{O}=\mathrm{Ca}^{2+}+2 \mathrm{HCO}_{3}^{-}
$$

and its related law of mass action:

$$
K_{\text {eqcalcite }}=\frac{a \mathrm{Ca}^{2+} a^{2} \mathrm{HCO}_{3}^{-}}{p \mathrm{CO}_{2}}
$$



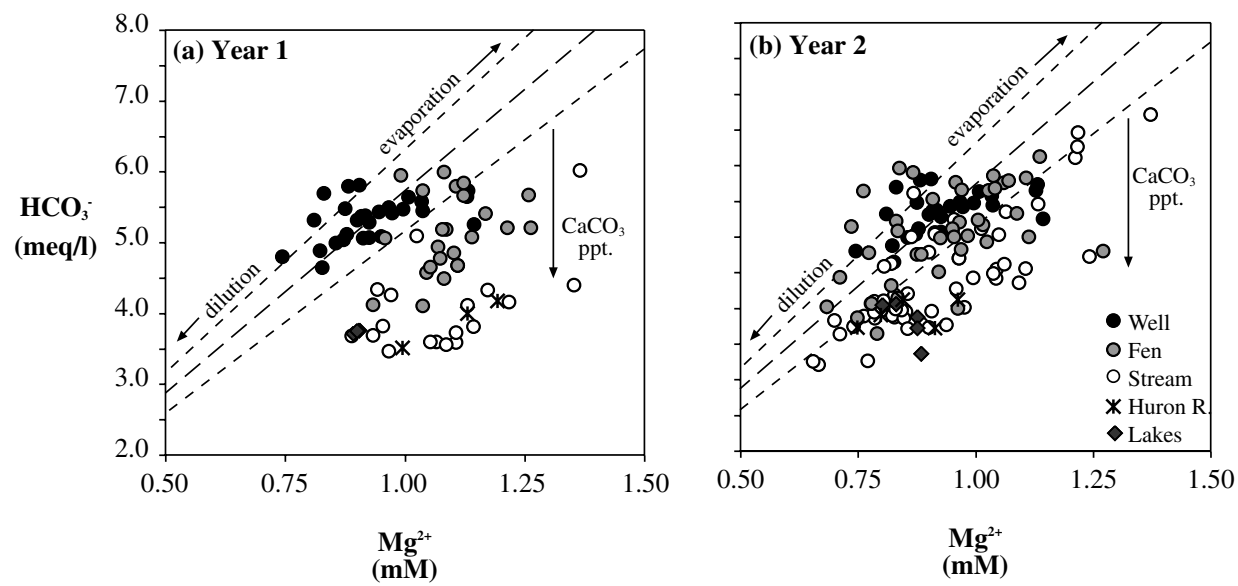

Figure 6. $\mathrm{HCO}_{3}^{-}$vs. $\mathrm{Mg}^{2+}$ for Years 1 and 2 for ground and surface waters in Portage and Ore Creek catchments. The solid line indicates a best fit through the groundwater data and represents the average $\mathrm{Mg}^{2+} / \mathrm{HCO}_{3}^{-}$molar ratio (0.174) taken from the groundwater. The dashed lines represent the standard deviation of the $\mathrm{Mg}^{2+} / \mathrm{HCO}_{3}^{-}$mole ratio. The fen water, stream water, lake water and Huron River all fall off this line indicating the loss of $\mathrm{HCO}_{3}^{-}$relative to $\mathrm{Mg}^{2+}$ in all the surface waters when compared to the groundwater. Year 1 of the study shows a greater offset from the line than Year 2.

where, $a$ is the ion activity. Groundwaters in this study have an average $p \mathrm{CO}_{2}$ of $10^{-2.15} \mathrm{~atm}$. The surface waters approach a $p \mathrm{CO}_{2}$ value of $10^{-3.5} \mathrm{~atm}$. and approach equilibrium with the atmosphere. The loss of $\mathrm{CO}_{2}$ is the main driver of increased saturation states for calcite, with changes in temperature and fluid mixing playing relatively small roles.

The stream and fen/lake waters reach approximately 30 times saturation with respect to calcite as a result of $\mathrm{CO}_{2}$ degassing. Studies of natural freshwater systems have shown that IAP/K values must exceed 5-10 times saturation before calcium carbonate precipitation occurs (Herman and Lorah, 1987; Jacobson and Usdowski, 1975; Lorah and Herman, 1988; Suarez, 1983). Many factors affect carbonate growth kinetics including availability of nucleation sites (Suarez, 1983), inhibition by $\mathrm{Mg}^{2+}$ and $\mathrm{PO}_{4}{ }^{3-}$ (Suarez, 1983; Zhang and Dawe, 2000), and DOC concentrations in excess of $0.05 \mathrm{mM}$ (Lebron and Suarez, 1996, 1998). The Huron watershed has an average $\mathrm{Mg}^{2+} / \mathrm{Ca}^{2+}$ ratio of approximately 0.5 , which could have slight effect on the growth rate of calcite. Except for lake waters, $\mathrm{PO}_{4}{ }^{3-}$ concentrations are below detection $(1 \mu \mathrm{M})$ in most samples and therefore would also be expected to have little effect on the precipitation of calcium carbonate. DOC values for the Huron watershed are in excess of those shown to decrease calcite precipitation rates. The average surface water DOC value is close to $1 \mathrm{mM}$. 

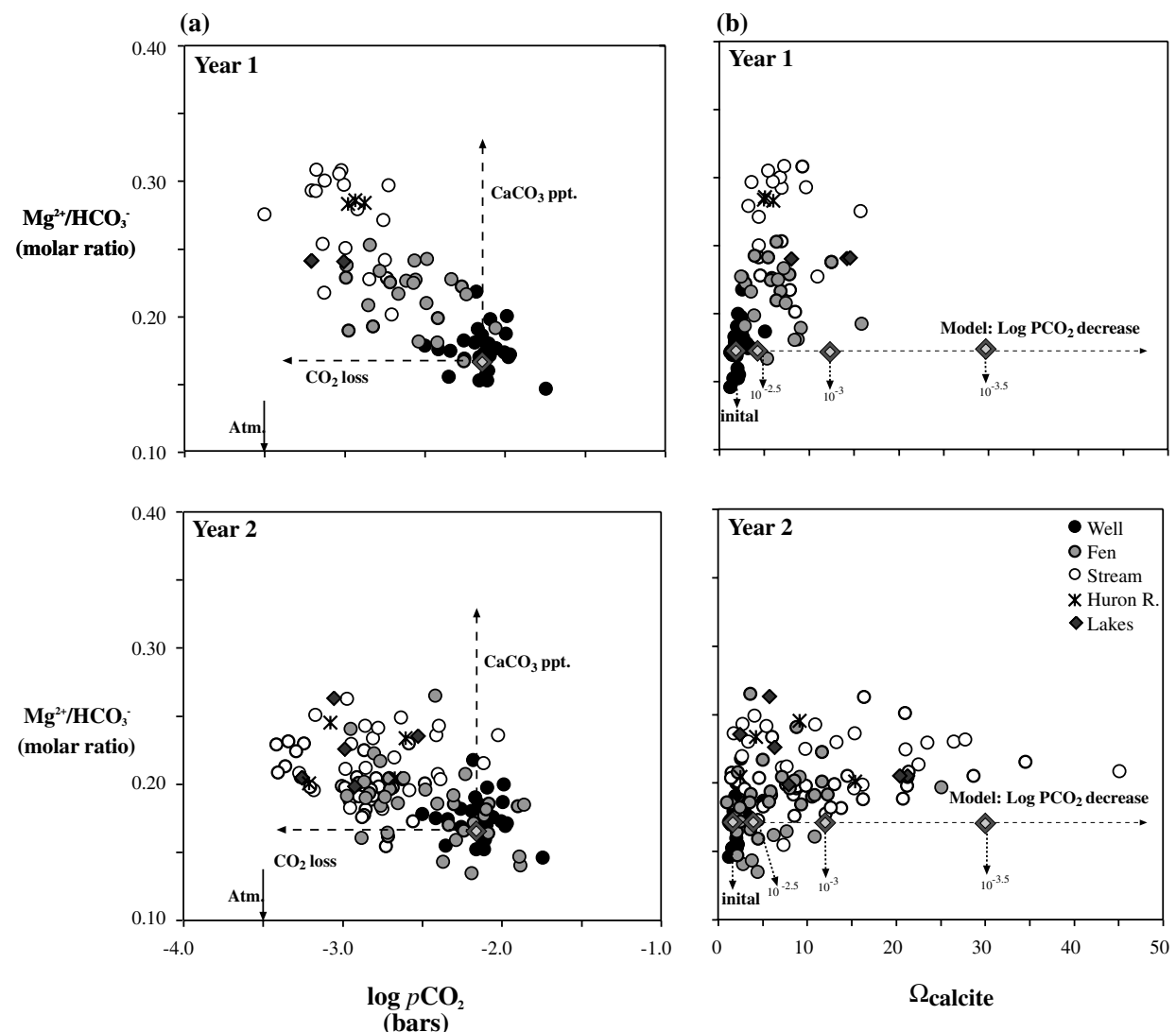

Figure 7. (a) $\mathrm{Mg}^{2+} / \mathrm{HCO}_{3}^{-}$vs. $\log \mathrm{pCO}_{2}$ relationships for Year 1 show higher $\mathrm{Mg}^{2+} /$ $\mathrm{HCO}_{3}^{-}$mole ratio than Year 2. A dashed line indicates the direction the $\mathrm{Mg}^{2+} / \mathrm{HCO}_{3}^{-}$mole ratio moves relative to the removal of $\mathrm{HCO}_{3}^{-}$during the precipitation (ppt.) of calcium carbonate. A second dashed line indicates the direction of $\mathrm{CO}_{2}$ degassing and the decrease in $p \mathrm{CO}_{2}$ as $\mathrm{CO}_{2}$ is lost to the atmosphere. (b) $\mathrm{Mg}^{2+} / \mathrm{HCO}_{3}^{-}$vs. $\Omega$ calcite shows that Year 1 of the study does not achieve the degree of supersaturation that Year 2 does, up to 45 times saturation. Year 1 however, has the higher $\mathrm{Mg}^{2+} / \mathrm{HCO}_{3}^{-}$mole ratios indicating that the saturation states are held in check by the back precipitation of calcium carbonate. A dashed line indicates direction of $\mathrm{CO}_{2}$ degassing. Diamonds indicate modeled $\log \mathrm{pCO}_{2}$ values for waters that undergo degassing without the back precipitation of calcium carbonate.

Changes in the $\mathrm{Mg}^{2+} / \mathrm{HCO}_{3}^{-}$ratio are driven by amount of calcium carbonate precipitation and indicate which environments in the catchment are the main loci of precipitation. The relationship between calcium carbonate precipitation and $\mathrm{Mg}^{2+} / \mathrm{HCO}_{3}^{-}$ratio can be further constrained by comparing the ratio to the values of carbonate parameters of the waters. Figure 7a shows the $\mathrm{Mg}^{2+} / \mathrm{HCO}_{3}^{-}$ratio versus $\log \mathrm{pCO}_{2}$. As outlined earlier, an increasing $\mathrm{Mg}^{2+} / \mathrm{HCO}_{3}^{-}$ratio is an indication of $\mathrm{HCO}_{3}^{-}$loss. The loss of 
$\mathrm{CO}_{2}$ generally tracks the trend of increasing $\mathrm{Mg}^{2+} / \mathrm{HCO}_{3}^{-}$ratios. Year 1 shows a stronger increase in $\mathrm{Mg}^{2+} / \mathrm{HCO}_{3}^{-}$ratios with $\mathrm{CO}_{2}$ degassing than does Year 2. Groundwaters have the highest $p \mathrm{CO}_{2}$ values (avg. $10^{-2.15} \mathrm{~atm}$.) and the lowest $\mathrm{Mg}^{2+} / \mathrm{HCO}_{3}^{-}$values (avg. $0.176 \pm 0.016$ ). The $\mathrm{Mg}^{2+} / \mathrm{HCO}_{3}^{-}$ ratio of the fen and stream waters increase $(\sim 0.30)$ as they evolve towards atmospheric $p \mathrm{CO}_{2}$ values $\left(10^{-3.5} \mathrm{~atm}\right.$.).

Relations between the amount of precipitation (changes in $\mathrm{Mg}^{2+} / \mathrm{HCO}_{3}^{-}$ ratios) and calcite saturation state are shown in Figure 7b. Samples collected during Year 2 of the study attain and maintain higher supersaturation for calcite than Year 1. Calcite saturation state responds to $\mathrm{CO}_{2}$ degassing, carbonate precipitation and $\mathrm{Ca}^{2+}$ pollution to varying degrees. Year 1 data show carbonate precipitation has relieved calcite supersaturation, although the waters remain significantly supersaturated. The Huron River site at Ann Arbor can be considered an integrator of the processes occurring in the headwater portions of the watershed. In general the waters show the greatest increase in $\mathrm{Mg}^{2+} / \mathrm{HCO}_{3}^{-}$ratios between $\Omega$ calcite values of 5-10 times saturation, the range shown to be the threshold to calcium carbonate precipitation in other natural systems (Herman and Lorah, 1987; Jacobson and Usdowski, 1975; Lorah and Herman, 1988; Suarez, 1983). Year 1 (Figure 7b) shows the highest $\mathrm{Mg}^{2+} / \mathrm{HCO}_{3}^{-}$ratios at approximately 5-10 times saturated for calcite with a few samples above 10 times saturation.

\section{Discussion}

\subsection{MASS BALANCE CALCULATIONS: CARBONATE PRECIPITATION AND DISCHARGE}

Locations of carbonate precipitation in the Huron River watershed and their relations to the drainage system architecture can be quantified by evaluating the mass balance of carbonate precipitated per liter of stream water at sites along the flow path from headwater catchments to the main channel. Alkalinity loss is calculated assuming that the average groundwater $\mathrm{Mg}^{2+} / \mathrm{HCO}_{3}^{-}$ratio is the starting value for surface waters in the Huron watershed. Changes in the $\mathrm{Mg}^{2+} / \mathrm{HCO}_{3}^{-}$ratios quantify the amount gained or lost according to the equation:

$$
\mathrm{HCO}_{3(\text { predictedSWvalue })}^{-}=\left(\frac{\mathrm{HCO}_{3}^{-}}{\mathrm{Mg}^{2+}}\right)_{(\text {averageGW })} \times \mathrm{Mg}_{(\text {measuredSW })}^{2+},
$$

where $\mathrm{SW}$ is the surface water and GW is the groundwater. The value of the $\mathrm{Mg}^{2+} / \mathrm{HCO}_{3}^{-}$ratio is $0.176 \pm 0.016$. The uncertainty in the alkalinity loss mass balance is $\pm 0.5 \mathrm{meq} / \mathrm{l}$, when analytical uncertainties for cation and alkalinity determinations are included in the error analysis. 
Figure $8 \mathrm{a}-\mathrm{c}$ presents the temporal and spatial influences on the mass balance for alkalinity loss in the Huron River watershed. Figure 8a shows the actual USGS stream gauge discharge data at Ann Arbor for the period just before and during the study interval as well as the average annual values over the entire period of record ( 87 years). In Figure $8 b$, the observed alkalinity losses are compared for stream vs. fen locations. Most fen and stream samples during Years 1 and 2 have lost significant amounts of alkalinity, most likely due to the precipitation of calcium carbonate. Only a few samples taken from the fen drainages exhibit an increase in alkalinity, but even these are largely within the uncertainty of the calculations $( \pm 0.5 \mathrm{meq} / \mathrm{l})$. Taken together, the data indicate that both fen and stream waters have experienced significant alkalinity losses.Another way to view the alkalinity loss patterns is to consider the differences in various reservoirs of the drainage system. Figure $8 \mathrm{c}$ shows alkalinity losses over the study period comparing the main channel of the Huron River near Dexter, with Halfmoon Lake water and with streams sampled before and after passing through the lake systems. It appears that both fens and lake settings have experienced carbonate precipitation and that these changes have the most profound effect on the main river channel chemistry during Year 1 , the period of lowest discharge in the watershed (see Table II and Figure 8a).

These mass balances can also be viewed on a longer temporal scale and better calibrated to location specific discharge values. The USGS discharge and concurrent chemical data shown in Figure $5 \mathrm{a}-\mathrm{c}$ for the four gauging sites can be used to evaluate the amount of $\mathrm{HCO}_{3}^{-}$loss, again assuming that the groundwater ratio for $\mathrm{Mg}^{2+} / \mathrm{HCO}_{3}^{-}$is the starting point for the stream waters. Figure 9a shows alkalinity loss versus normalized discharge for the Huron River at the four gauging stations, which have both chemical and discharge data for the samples. As suggested by the patterns of alkalinity concentrations shown in Figure 6a, the lower periods of discharge have the greatest alkalinity loss. At higher discharges alkalinity losses are less than half of that observed during low flow conditions. Importantly, the most significant losses in alkalinity are associated with periods when discharge is below long term average values for the catchments (see Table I).

Alkalinity loss data collected in our study for the two historic USGS gauge sites (Portage@ Tiplady and Huron River near Dexter) are plotted against normalized discharge in Figure $9 \mathrm{~b}$ and c. No current gauge data is collected at these two sites, necessitating the estimation of discharge as detailed in Section 2.6. Year 1 samples exhibit higher alkalinity losses over the range of normalized discharges $\left(2-151 / \mathrm{km}^{2} \mathrm{~s}\right)$, while Year 2 shows lower alkalinity loss values over the a smaller range of discharges $\left(5-151 / \mathrm{km}^{2} \mathrm{~s}\right)$. Thus, the data gathered in this study suggests that low discharge periods are associated with greatest alkalinity losses and the denser data set from the USGS provides additional support for this assertion. 

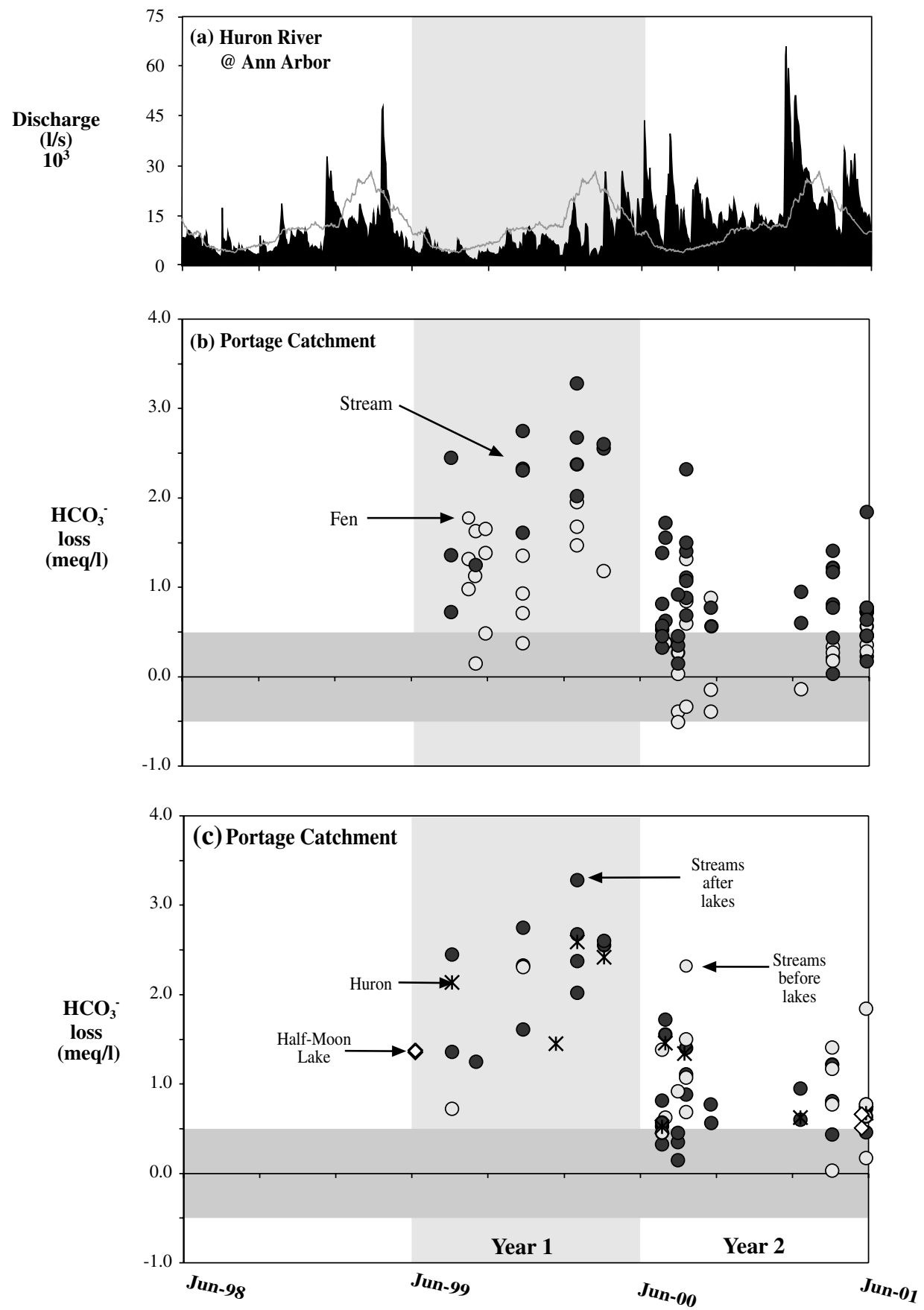

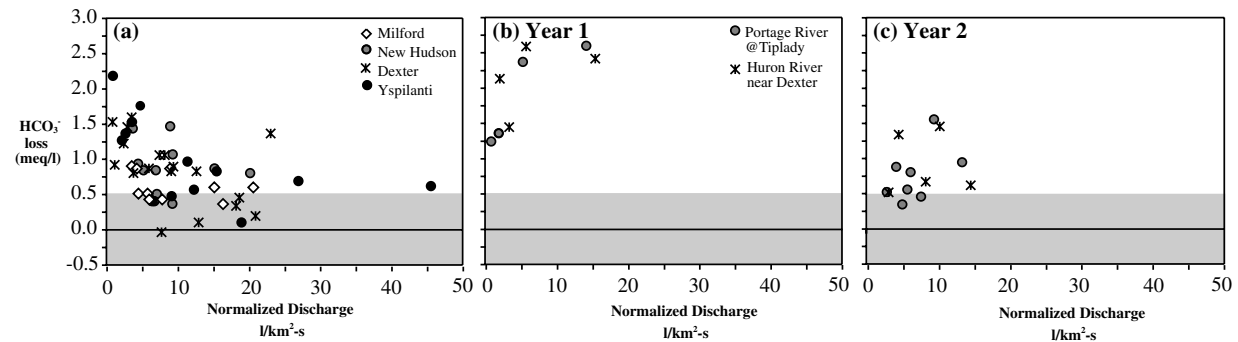

Figure 9. Alkalinity loss (meq/l) vs. normalized discharge $\left(1 / \mathrm{km}^{2} \mathrm{~s}\right)$. (a) The Huron River taken from four USGS sites with both chemical and discharge data. The details of the stations are given in Table I. The data show that the lower flow volumes have higher alkalinity lost values. The gray band indicates the uncertainty in the zero point based on the standard deviation of the $\mathrm{Mg}^{2+} / \mathrm{HCO}_{3}^{-}$values for the groundwater samples. (b) Data from the Huron River (this study) and Portage @ Tiplady (1) for Year 1. (c) Data from the Huron River (this study) and Portage @ Tiplady (1) for Year 2. Year 1 has higher alkalinity loss values and lower discharge values than Year 2.

\subsection{RIVERINE FLUXES VERSUS CARBONATE ACCUMULATION RATES IN LAKES AND FENS}

The average amount of calcium carbonate precipitated within the Huron watershed was determined by the average carbonate alkalinity $\left(\mathrm{HCO}_{3}^{-}\right)$loss $(0.86 \mathrm{meq} / \mathrm{l})$ and average discharge $(10,050.3 \mathrm{l} / \mathrm{s})$ from historical USGS chemical and discharge data from the Huron River gauge site near Dexter (41730000). The amount of calcium carbonate precipitated from the Huron watershed above the gauge is $1.36 \times 10^{10} \mathrm{~g}$ per year. Normalized to the amount of area drained (see Table I), this flux is $1.01 \times 10^{7} \mathrm{~g}$ per $\mathrm{km}^{2}$ year. However, the geochemical changes in the stream waters are most pronounced in the headwater portions of the catchments, which are the locus of carbonate precipitating fens and lakes.

Figure 8. (a) Discharge for the Huron River@ Ann Arbor (4174500) for the year previous to the study and Years 1 and Year 2 of the study is shown with the dark shaded area. The light line indicates the average discharge over 87 years of data. Year 1 clearly has discharge below the average, where as Year 2 has discharge above the average. (b) Alkalinity loss (removed) from the Portage Catchment stream and fen waters as determined by the predicted ratio of $\mathrm{Mg}^{2+} / \mathrm{HCO}_{3}^{-}$from the sampled groundwaters is shown in the second graph. The year June 1999-June 2000 has the greatest degree of alkalinity loss. The increased $\mathrm{HCO}_{3}^{-}$loss from the surface waters during Year 1 is accompanied by the lower discharge. (c) The third graph shows $\mathrm{HCO}_{3}{ }^{-}$loss with the Huron River, Halfmoon Lake and streams before and after lakes. Stream water that has not passed thorough a lake tends to be as evolved as stream water that has passed through a lake. The Huron River samples are also as evolved as the other samples indicting that the samples are modified before they reach the main channel of the Huron River. 
In order to focus on lakes and fens as reservoirs of carbonate accumulation, a mass balance calculation is made of the amount of carbonate loss within the Portage Catchment, the main area of study at the historical USGS gauge located at Portage at Tiplady (4172500). A conservative estimate was calculated using the average alkalinity loss from the Huron River near Dexter $(0.860 \mathrm{meq} / \mathrm{l})$ rather than the value calculated during the 2 years of the present study at the Portage at Tiplady sample site. This was done to eliminate the potential bias of data collected in this study to higher carbonate production due to the particularly low discharges of Year 1 of the study.

The average discharge $(1384 \mathrm{l} / \mathrm{s})$ along with the average alkalinity loss indicates a loss of $1.88 \times 10^{9} \mathrm{~g}$ per year (a conservative estimate) this equates $9.2 \times 10^{6} \mathrm{~g}$ per $\mathrm{km}^{2}$ year in the Portage catchment. The lakes in the Portage catchment comprise approximately $10 \%\left(20.4 \mathrm{~km}^{2}\right)$ of the surface area. If all the carbonate precipitating in the catchment is forming/accumulating in the lakes then $9.17 \times 10^{7}$ grams per $\mathrm{km}^{2}$ year is accumulating within the lake basins of the Portage Catchment in the Huron River Watershed.

This carbonate production rate is more than twice the short-term accumulation rate of $4.43 \times 10^{7} \mathrm{~g}$ per year observed in Littlefield Lake in Michigan by Dustin et al. (1986). The authors noted that the short-term rate of calcium carbonate is 3-7 times too low to account for the amount of carbonate accumulated over time in Littlefield Lake. Other authors have noted a similar trend and have indicated that the rates of calcium carbonate production in marl lakes have decreased over the Holocene (Dean, 1999; Dustin et al., 1986; Wetzerl, 1968). The rate of modern day carbonate production appears to have decreased from past rates making accumulation over time difficult to determine.

\subsection{EXPORT OF $\mathrm{HCO}_{3}^{-}$: INFLUENCE OF CARBONATE PRECIPITATION}

The precipitation of calcium carbonate from the Huron River watershed (taken near Dexter) decreases the average $\mathrm{HCO}_{3}^{-}$concentration by nearly $20 \%$, from $4.57 \mathrm{meq} / 1$ (predicted) to $3.71 \mathrm{meq} / 1$ (actual). Although a reduction in the export of alkalinity from the Huron Watershed is observed, this reduction would be nearly impossible to infer from the chemistry downstream in the greater St. Lawrence-Great Lakes Watershed. The alkalinity for the St. Lawrence River is less than 2 meq/l (Holland, 1978; Yang et al., 1996) and is reflective of upstream processes (i.e., carbonate precipitation, dilution). In addition to the low alkalinity concentrations, the St. Lawrence River is typically near saturation for calcite (Holland, 1978; Yang et al., 1996). The type of substrate and the land use with in a watershed can greatly influence the dissolved solutes, saturation states and dissolved $\mathrm{CO}_{2}$ with in a river system. Telmer and Veizer, (1999) suggest that watersheds operate at different weathering zone $p \mathrm{CO}_{2}$ 's, which in turn control the stream chemistry by 
regulating rock weathering within the watershed. The recent study of the Mississippi River by Raymond and Cole (2003), indicate that the long-term average of alkalinity concentration of the river is increasing. They attribute this to change in land use within the Mississippi Basin. The thickness of soils (Telmer and Veizer, 1999) and type of land use (i.e., agriculture vs. forested) (Raymond and Cole, 2003) are the main controls on the $p \mathrm{CO}_{2}$ and in turn the carbonic acid in contact with minerals available to weather. Land use changes and the increases in atmospheric $\mathrm{CO}_{2}$ in turn will influence the $p \mathrm{CO}_{2}$ in the shallow soils and potentially increase the amount of solutes, including $\mathrm{HCO}_{3}^{-}$draining terrestrial landscapes. However, the back precipitation may limit the predicted export of $\mathrm{HCO}_{3}^{-}$to the world's oceans.

The results obtained on the carbonate geochemistry in streams and shallow groundwaters suggest that a more detailed, systematic and temporally controlled study of these systems may provide valuable new insights to the functioning of terrestrial carbonate weathering systems. This study indicates that Holland's (1978) simplified theory on carbonate saturation states within the world's major rivers underestimates the possibility for sustained supersaturation with respect to calcite. Rivers in areas draining carbonates are likely to be at or above saturation for calcite regardless of discharge. Watersheds are commonly characterized by $\mathrm{HCO}_{3}^{-}$flux from the mouth of the drainage system, however this relationship limits the understanding of the processes which actually regulate the carbonate dissolution flux.

\section{Summary and Conclusions}

The suite of geochemical analysis obtained on the surface waters and shallow groundwaters of the Portage and Ore Creek catchments of the Huron River watershed, MI provides a spatially resolved view of processes regulating the dissolved inorganic carbon mass balance within this watershed. The dissolution of calcite and dolomite within the geologically young soils developed on glacial deposits covering the region greatly influence the water chemistry within the watershed. Accordingly, the groundwaters and surface waters in this study are predominantly $\mathrm{Ca}^{2+}-\mathrm{Mg}^{2+}-\mathrm{HCO}_{3}^{-}$waters.

Many other studies that examine the freshwater precipitation of carbonate, mainly as tufa, utilize the $\mathrm{Ca}^{2+}$ and alkalinity concentrations in waters to determine the mass balance of carbonate precipitation. The surface waters in the Huron Watershed, however, have excess $\mathrm{Na}^{+}, \mathrm{Cl}^{-}$and $\mathrm{Ca}^{2+}$ relative to groundwaters as a result of anthropogenic $\mathrm{NaCl}$ and $\mathrm{CaCl}_{2}$ salts. This means that the $\mathrm{Ca}^{2+} / \mathrm{HCO}_{3}^{-}$(alkalinity) relationship cannot be used to arrive at an accurate mass balance of carbonate dissolution or precipitation.

The examination of changes in the surface water $\mathrm{Mg}^{2+} / \mathrm{HCO}_{3}^{-}$ratio relative to the ratio set by the groundwater is the most useful parameter to quantify carbonate production within the Huron River watershed. This is 
possible because of the relatively constant value of $\mathrm{Mg}^{2+} / \mathrm{HCO}_{3}^{-}$in the glacial drift groundwaters and their close hydrogeologic connection to surface waters. The carbonate parameters indicate that the surface waters are highly evolved when compared to the starting conditions set by the groundwater. The increase of $\mathrm{Mg}^{2+} / \mathrm{HCO}_{3}^{-}$ratio in the surface waters indicates that carbonate precipitation occur as $\mathrm{CO}_{2}$ degasses. The corresponding $\Omega$ calcite indicates that these waters can sustain supersaturation with respect to calcite without back precipitation even though waters exceed 10 fold supersaturation values. Surface water samples from Year 1 of the study have the highest $\mathrm{Mg}^{2+} / \mathrm{HCO}_{3}^{-}$ratios and $\Omega$ calcite values for these waters does not exceed 15 times saturation, a value three times lower than that observed during Year 2 of the study.

The alkalinity loss values for surface water samples attain their maximum values during Year 1 of the study when the discharge of the Huron River was well below normal. Samples from Year 2, a period characterized by riverine discharge values above normal, have more modest alkalinity losses. Importantly the data for the main channel of the Huron River do not show additional alkalinity loss relative to the waters discharged from the smaller headwater catchments, which include fen and lake systems.

The export of dissolved inorganic carbon is decreased from the Huron River watershed by the removal of alkalinity from the surface waters. The relationships for the alkalinity and $\mathrm{Ca}^{2+}+\mathrm{Mg}^{2+}$ versus discharge indicate that alkalinity and $\mathrm{Ca}^{2+}+\mathrm{Mg}^{2+}$ values are at their lowest concentrations during the lowest discharges for the Huron River. This is supported by the relationship between alkalinity loss and discharge, where the highest values are observed during the lowest flow periods. These relationships indicate that the flux of carbonate removed from the weathering zone of the soil is decreased only slightly due to the back precipitation of calcium carbonate within the watershed.

The next several centuries will likely see increases in atmospheric $\mathrm{CO}_{2}$ concentrations and terrestrial carbon cycling due to fertilization effects and changes in land use. All of these tend to intensify the short-term transport of carbon derived from carbonate rock weathering. Our study shows that carbonate weathering flux dynamics within watersheds need to be examined on a small spatial scale. More detailed studies of carbonate saturation state and carbonate precipitation losses within watersheds will permit observed variations in $p \mathrm{CO}_{2}$ values and $\mathrm{HCO}_{3}^{-}$carrying capacity to be related mechanistically to carbonate fluxes from terrestrial environments.

\section{Acknowledgements}

This research was supported by National Science Foundation grant EAR 0208182 to L. M. Walter and a University of Michigan OVPR Award to L. M. Walter and D. E. Goldberg. The authors are grateful to C. Lambert 
and M. Handyside for major element analysis, E. Williams, P. McCall and M. Taylor for their help with field sampling, J. Teranes for the lake data, and C. Hershock and D. Goldberg for guidance in wetland science and the location of the fens. The helpful comments provided by the two journal reviewers greatly improved the paper.

\section{References}

Almendinger J. E. and Leete J. H. (1998a) Peat characteristics and groundwater geochemistry of calcareous fens in the Minnesota River Basin, USA Biogeochemistry 43, 17-41.

Almendinger J. E. and Leete J. H. (1998b) Regional and local hydrogeology of calcareous fens in the Minnesota River Basin, USA. Wetlands 18, 184-202.

Andrews J. A. and Schlesinger W. A. (2001) Soil $\mathrm{CO}_{2}$ dynamics, acidification, and chemical weathering in a temperate forest with experimental $\mathrm{CO}_{2}$ enrichment. Global Biogeochem. Cycles 15, 149-162.

Aucour A.-M., Sheppard S. M. F., Guyomar O. and Wattelet J. (1999) Use of ${ }^{13} \mathrm{C}$ to trace origin and cycling of inorganic carbon in the Rhône river system. Chem Geol. 159, 87-105.

Barth J. and Veizer J. (1999) Carbon cycle in St. Lawrence aquatic ecosystems at Cornwall (Ontario), Canada: seasonal and spatial variations. Chem. Geol. 159, 107-128.

Barth J., Cronin A. A., Dunlop J., Kalin R. M. (2003) Influence of carbonates on the riverine carbon cycle in an anthropogenically dominated catchment basin: evidence from major elements and stable carbon isotopes in the Lagan River (N. Ireland). Chem. Geol. 200, 203-216.

Berner E. K. and Berner R. A. (1987) The Global Water Cycle: Geochemistry and Environment: Englewood Cliffs, N. J., Prentice-Hall, 397 pp.

Blum J. D., Grazis C. A., Jacobson A. D. and Chamberlain C. P. (1998) Carbonate versus silicate weathering in the Raikhot Watershed within the High Himalayan Crystalline Series. Geology 26, 411-414.

Brady N. and Weil, R. R. (1996) The nature and properties of soils: Upper Saddle River, NJ, Prentice Hall, 740 pp.

Dean W. E. (1999) The carbon cycle and biogeochemical dynamics in lake sediments. $J$. Paleolimnol. 21, 375-393.

Dorr Jr. J. A., and Eschman, D. F. (1970) Geology of Michigan. Ann Arbor, Univ. of Michigan Press, 476 pp.

Drever J. I., (1997) The geochemistry of natural waters: surface and groundwater environments: Upper Saddle River, NJ, Prentice Hall, 436 pp.

Drysdale R. N., Taylor M. P. and Ihlenfeld C. (2002) Factors controlling the chemical evolution of travertine-depositing rivers of the Barkly karst, northern Australia. Hydrol. Process. 16, 2941-2962.

Dustin N. M., Wilkinson B. H. and Owen R. M. (1986) Littlefield Lake, Michigan; carbonate budget of Holocence sedimentation in a temperate-region lacustrine system. Limnol. Oceanography 31, 1301-1311.

Farrand W. R. (1982) Quaternary Geology of Southern Michigan: State of Michigan, Deptartment of Natural Resources, Geological Survey, Lansing, Mich.

Gaillardet J., Dupre B., Louvat P. and Allegre C. J. (1999) Global silicate weathering and $\mathrm{CO}_{2}$ consumption rates deduced from the chemistry of large rivers. Chem Geol. 159, 3-30.

Garrels R. M. and Mackenzie F. T. (1971) Evolution of Sedimentary Rocks: W. W. Norton and Company, New York, 397 pp.

Glaser P. H., Janssens J. A. and Siegel. D. I. (1990) The response of vegetation to chemical and hydrological gradients in the Lost River peatland, northern Minnesota. J. Ecol. 78, 1021-1048. 
Grannemann N. G., Hunt R. J., Nicholas J. R., Reilly T. E., and Winter T. C. (2000) The Importance of Ground Water in the Great Lakes Region. USGS Water-Resources Investigations Report 00-4008: 1-14.

Grosbois C., Négrel Ph., Fouillac C. and Grimaud D. (2000) Dissolved load of the Loire River: Chemical and isotopic characterization. Chem. Geol. 170, 179-201.

Hamilton J. G., DeLucia E. H., George K., Naidu S. L., Finzi A. C. and Schlesinger W. H. (2002) Forest carbon balance under elevated $\mathrm{CO}_{2}$. Ecosys. Ecol. 131, 250-260.

Herman J. S. and Lorah M. M. (1987) $\mathrm{CO}_{2}$ outgassing and calcite precipitation in Falling Spring Creek, Virgina, USA. Chem. Geol. 62, 251-262.

Herman J. S. and Lorah M. M. (1988) Calcite precipitation rates in the field: Measurement and prediction for travertine-depositing stream. Geochim. Cosmochim. Acta. 52, 2347-2355.

Holland H. D. (1978) The Chemistry of the Atmosphere and Oceans: John Wiley and Sons, New York, $351 \mathrm{pp}$.

Jacobson R. L. and Usdowski E. (1975) Geochemical controls on a calcite precipitating spring. Contributions Mineral. Petrol. 51, 65-74.

Jacobson A. D., Blum J. D., Chamberlain C. P., Poage M. A. and Sloan V. F., (2002) Ca/Sr and Sr isotope systematics of a Himalayan glacial chronosequence: carbonate versus silicate weathering rates as a function of landscape surface age. Geochem. Cosmochim. Acta. 66, 13-37.

Kano A., Sakuma K., Kaneko N. and Naka T. (1998) Chemical properties of surface waters in the limestone regions of western Japan: Evaluation of chemical conditions for the deposition of tufas. J. Sci. Hiroshima Univ. Ser. 11, 11-22.

Karim A. and Veizer J. (2000) Weathering processes in the Indus River Basin: implications from riverine carbon, sulfur, oxygen, and strontium isotopes. Chem. Geol. 170, 153-177.

Kempe S. (1982) Long-term records of $\mathrm{CO}_{2}$ Pressure fluctuations in fresh waters. In Transport of carbon and minerals in major world rivers, (ed. Degens, E. T. Kempe, S. Soliman, H. and Herrerapp, R. pp. 91-323. Hamberg: SCOPE-UNEP.

Kharaka Y. K., Gunter W. D. Aggarwal P. K., Perkins E. H. and DeBraal J. D. (1988) SOLMINEQ.88: A computer program for geochemical modeling of water-rock interactions: U.S. Geological Survey.

Komor S. C. (1994) Geochemistry and hydrology of a calcareous fen within the Savage Fen wetlands complex, Minnesota, USA. Geochim. Cosmochim. Acta. 58, 3353-3367.

Ku T. C. W. (2001) Organic Carbon - Mineral Interactions in Near Surface Environments: Implications for the Global Carbon Cycle. Ph. D. thesis: Ann Arbor, University of Michigan.

Langmuir D., (1997) Aqueous Environmental Geochemistry: N. J., Prentice-Hall, Englewood Cliffs, $600 \mathrm{pp}$.

Lebron I. and Suarez D. L. (1996) Calcite nucleation and precipitation kinetics as affected by dissolved organic matter at $25^{\circ} \mathrm{C}$ and $\mathrm{pH}>7.5$. Geochem. Cosmochim.Acta 60, 2765-2776.

Lebron I. and Suarez D. L. (1998) Kinetics and mechanisms of precipitation of calcite as affected by P-CO2 and organic ligands at $25^{\circ} \mathrm{C}$. Geochim. Cosmochim. Acta 62, 405-416.

Lorah M. M. and Herman J. S. (1988) The chemical evolution of a travertine-depositing stream: Geochemical processes and a mass transfer reaction. Water Resourc. Res. 24, 1541-1552.

Lu G., Zheng C., Donahoe R. J. and Lyons W. B. (2000) Controlling processes in a $\mathrm{CaCO}_{3}$ precipitating stream in Huanglong Natural Science District, Sichuan, China. J. Hydrol. 230, $34-54$.

Mackenzie F. T., Lerman A., Ver L. M. B. (1998) Role of the continental margin in the global carbon balance during the past three centuries. Geology 26, 423-426.

Mackenzie F. T., Ver L. M., Sabine C., Lane M. and Lerman A. (1993) C, N, P, S global biogeochemical cycles and modeling of global change. In Interactions of $C, N, P$ and $S$ Biogeochemical Cycles and Global Change, (ed. Wollast, R. Mackenzie F. T. and L. Chou), pp. 1-62. Springer-Verlag. Berlin. 
Meybeck M. (1987) Global chemical weathering of surficial rocks estimated from river dissolved loads. Am. J. Sci. 287, 401-428.

Millot R., Gaillardet J., Dupré B., and Allègre C. J. (2003) Northern latitude chemical weathering rates:Clues from the Mackenzie River Basin, Canada. Geochim. Cosmochim. Acta 67, $1305-1329$.

Morse J. W. and Mackenzie F. T. (1990) Geochemistry of Sedimentary Carbonate. Elsevier.

Mulcahy J. (2003) Jury's still out on road brine, The Ann Arbor News. Ann Arbor, pp. B1, B3.

Pregitzer, K. S., Zak, D. R., Maziasz, J., DeForest, J., Curtis, P. S. and Lussenhop, J. (2000) Interactive effects of atmospheric $\mathrm{CO}_{2}$ and soil-N availability on fine roots of Populus tremulodies. Ecol. Applications 10, 18-33.

Raymond P. A. and Cole J. J. (2003) Increase in the export of alkalinity from North America's largest river. Science 301, 88-91.

Reardon E. J., Allison G. B. and Fritz P. (1979) Seasonal chemical and isotopic variations of soil $\mathrm{CO}_{2}$ at Trout Creek, Ontario. J. Hydrol. 43, 355-371.

Roy S., Gaillardet J. and Allègre C. J. (1999) Geochemistry of dissolved and suspended loads of the Seine river, France: Anthropogenic impact, carbonate and silicate weathering. Geochim. Cosmochim. Acta 63, 1277-1292.

Suarez D. L. (1983) Calcite supersaturation and precipitation kinetics in the Lower Colorado River, All American Canal and East Highline Canal. Water Resourc. Res. 19, 653-661.

Szramek, K., Walter, L. M. and McCall, P. (2004) Arsenic mobility in groundwater/surface water systems in carbonate-rich Pleistocene glacial drift aquifers (Michigan). Applied Geochem. 19, 1137-1155.

Telmer K. and Veizer J. (1999) Carbon fluxes, $\mathrm{pCO}_{2}$ and substrate weathering in a large northern river basin, Canada: Carbon isotope perspective. Chem. Geol. 159, 61-86.

Twenter F. R., Knutilla R. L. and Nowlin J. O. (1976) Water Resources of Washtenaw County, Michigan: Ann Arbor, United States Geological Survey in cooperation with the Washtenaw County Metropolitan Planning Commission, pp. 1-143.

U.S. Geological Survey (2001) National Water Information System (NWISWeb) data available on the World Wide Web, accessed [2001], at URL [http://waterdata.usgs.gov/nwis/].

Van Breenan N. and Protz R. (1988) Rates of calcium carbonate removal from soils. Can. J. Soil Sci. 68, 449-454.

Wachniew P. and Rozanski K. (1997) Carbon budget of a mid-latitude, groundwater-controlled lake: Isotopic evidence for the importance of dissolved inorganic carbon recycling. Geochim. Cosmochim. Acta 61, 2453-2465.

Wetzel R. G. (1970), Recent and postglacial production rates of a marl lake. Limnol. Oceanography 15, 491-503.

Williams E. L., Walter L. M., Ku T. C. W., Kling G. W. and Zak D. R. (2003) Effects of $\mathrm{CO}_{2}$ and nutrient availability on mineral weathering in controlled tree growth experiments. Global Biogeochem. Cycles 17 Art. No. 1041.

Yang C., Telmer K. and Veizer J. (1996) Chemical dynamics of the "St. Lawrence" riverine system: $\delta \mathrm{D}_{\mathrm{H} 2 \mathrm{O}}, \delta^{18} \mathrm{O}_{\mathrm{H} 2 \mathrm{O}}, \delta^{13} \mathrm{C}_{\mathrm{DIC}}, \delta^{34}$ sulfate, and dissolved ${ }^{87} \mathrm{Sr} /{ }^{86} \mathrm{Sr}$. Geochem. Cosmochim. Acta 60, 851-866.

Zaihua L., Svensson U., Dreybrodt W., Daoxian Y. and Buchmann D. (1995) Hydrodynamic control of inorganic calcite precipitation in Huanglong Ravine, China: Field measurements and theoretical prediction of deposition rates. Geochem. Cosmochim.Acta. 59, 3087-3097.

Zhang Y. and Dawe R. A. (2000) Influence of $\mathrm{Mg}^{2+}$ on the kinetics of calcite precipitation and calcite crystal morphology. Chem. Geol. 163, 129-138. 